CANADIANA

JUN 131988

Reserves

for

Nature

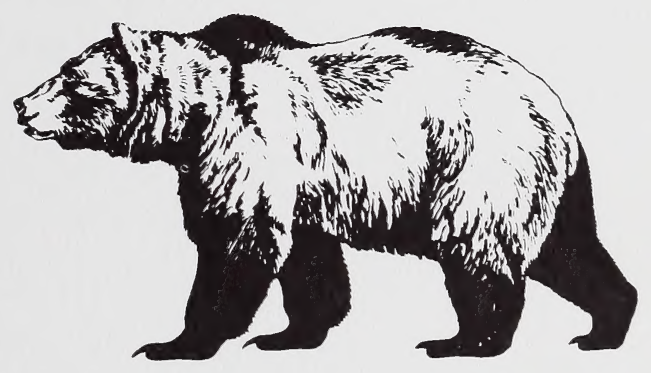

A Discussion Paper Prepared for the Alberta Conservation Strategy Project

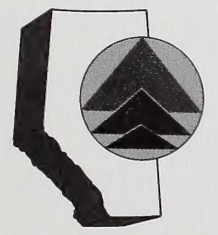


Digitized by the Internet Archive in 2015

https://archive.org/details/reservesfornatur00webb 


\section{Reserves For Nature}

Prepared by

Calvin Webb

Research Officer

Environment Council of Alberta

Published by

Environment Council of Alberta

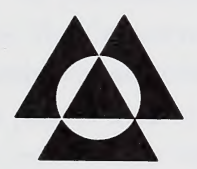

November 1987

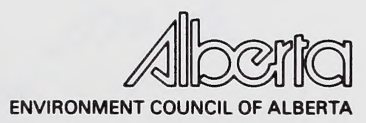

Distributed without charge as a public service. 
Additional copies of this publication may be obtained from:

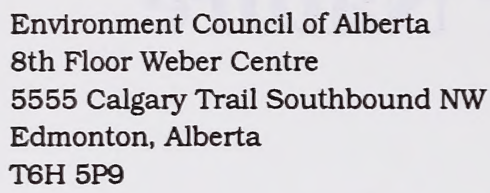

Phone (403)427-5792

Orders may also be placed through our electronic bulletin board at (403)438-5793 (24 hours per day).

This report may be cited as:

Webb, C. 1987. Reserves for Nature. ECA88-PA/CS-S1. Environment Council of Alberta, Edmonton. 


\section{FOREWORD}

In late 1985, the Public Advisory Committees to the Environment Council of Alberta began working toward a draft conservation strategy for Alberta. The Public Advisory Committees (PACs), comprising representatives of some 120 non-government organizations, are in many ways an ideal organization for developing a strategy that should touch the lives of all Albertans. The PACs bring together many diverse viewpoints, we are non-partisan, and we have members from across the province. Since the early days of the project, we have welcomed non-PAC participants, and have been delighted to receive the contributions of civil servants, industry spokespeople, academics, and the general public.

We have made progress since 1985: the Prospectus for an Alberta Conservation Strategy has been published and many meetings and workshops have been held. The principle of a conservation strategy increasingly has been endorsed by Albertans, and Alberta has been recognized across Canada as a leader in conservation strategy development. There have been important related events. For example, in September of 1987, every environment minister in Canada endorsed the final report of the National Task Force on Environment and Economy, which recommended that conservation strategies be in place in every province and territory by 1992 . This same report was endorsed by the First Ministers at their November, 1987 meeting.

We will have a conservation strategy for Alberta, we hope by 1990, the Canadian Year of the Environment. Our work continues in the expectation that all those who are interested will have a chance to contribute to the project, through public hearings or some other public participation process.

Since the publication of the Prospectus, the PACs have concentrated on preparing sectoral discussion papers. The Conservation Strategy Steering Committee determined early on to produce background papers on relevant sectors, such as agriculture, fish and wildlife, tourism, oil and gas, and others. These discussion papers look at the issues within each sector, but, more importantly, they investigate the interaction of each sector with the others. Their preparation has involved consulting with a wide range of interest groups - a conservation strategy principle in action - which has proven fruitful in developing ideas about the ultimate conservation strategy. These discussion papers will be used as background information for drafting a conservation strategy document and, perhaps, in the future, in public hearings on the draft conservation strategy. Reserves for Nature is one in the series of discussion papers.

Because there are as many opinions on our best future direction as there are Albertans, we welcome comments. The conservation strategy will be only as good as the work that goes into preparing it. Please address any comments on this discussion paper or others in the series to the Environment Council of Alberta at the address given on the page opposite. I would also encourage you to make your opinions known at public hearings or other events as they are held. Let's treat Alberta as if we plan to stay!
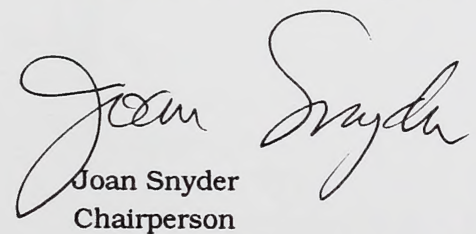

Conservation Strategy Steering Committee

Public Advisory Committees to the Environment Council of Alberta 


\section{ABOUT THIS DISCUSSION PAPER}

Several of the sectoral discussion papers deal directly or indirectly with the conservation of plants and animals for future use and enjoyment. Reserves for Nature has been prepared to examine the many issues surrounding the setting aside of reserves for conservation purposes, and the effect of human activity on the ability of reserves to meet the objectives set for them.

Reserves for Nature is not intended to be a thorough reference on the subject of nature reserves. The intent is to stimulate thinking about the setting aside of nature reserves to help accomplish the aims of the Alberta Conservation Strategy. Readers interested in more details may consult the references used to prepare the report.

\section{ACKNOWLEDGEMENTS}

Reserves for Nature has benefitted from the professional contacts, perspectives, reviews, and other help of many who are interested in conservation. The Public Advisory Committees to the Environment Council of Alberta (especially the Science Advisory Committee and the Environment Protection Sub-Committee) have been of great help to me in preparing this discussion paper. I wish to express my appreciation for the manuscript reviews provided me by Dr. Joan Snyder of Grande Prairie Regional College; Dr. Robert Holmberg of Athabasca University; and Dr. Guy Swinnerton, Dr. Bob Hudson, and Dr. Bill Fuller of the University of Alberta. All but Dr. Hudson are members of the Public Advisory Committees. Also, I am indebted to my staff colleagues at the Environment Council for their review comments and for the numerous other ways that they helped Reserves for Nature to completion, including, but not limited to, literature retrieval, typing, drafting, and editing. Thank you all for your assistance.

Calvin Webb

November 1987 


\section{Contents}

INTRODUCTION $\ldots \ldots \ldots \ldots \ldots \ldots \ldots \ldots \ldots \ldots \ldots \ldots$

BASIC BIOGEOGRAPHY $\ldots \ldots \ldots \ldots \ldots \ldots \ldots \ldots \ldots \ldots$

How Many Species Can an Island Sustain? . . . . . . 4

WHAT THE THEORY TELLS US ABOUT THE DESIGN OF NATURE

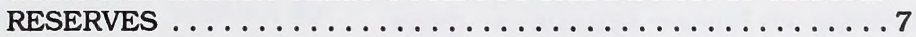

To Protect Rare Species or Typical Species? . . . . . . 7

How Large Should Nature Reserves Be? . . . . . . . . 8

How Should Reserves Be Arranged? . . . . . . . 13

HUMAN ACTIVITY AND NATURE RESERVES $\ldots \ldots \ldots \ldots \ldots 17$

CONCLUDING REMARKS $\ldots \ldots \ldots \ldots \ldots \ldots \ldots \ldots \ldots$

APPENDIX 1. POTENTIAL SITES EVALUATION . . . . . . 25

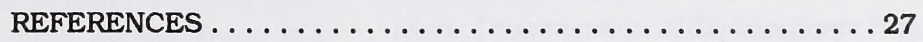





\section{Chapter 1}

\section{INTRODUCTION}

Extinctions of plant and animal species are a natural ecological and evolutionary process. Within historical times, however, the rates have accelerated (Kaufman 1986), to the point where, in the last decades of the twentieth century, the rate of extinction will be somewhere between 40 and 400 times the rate over geological time (Ehrlich 1982). The Global 2000 Report to the President predicted the loss of hundreds of thousands of species - between 15 and 20 percent of those on Earth - by the year 2000 (Council on Environmental Quality and the Department of State 1980). We are thought to be on the brink of causing a mass extinction comparable in magnitude to the half dozen or so that have been identified in the fossil record dating from the Cambrian Period, some 500 million years ago (Jablonski 1986).

For those of us alarmed by the trend, the arguments in favor of preserving the world's plant and animal species fall into three main categories. One of these is an ethical or moral one, that we humans have a duty to protect and help other species with whom we share the Earth. This sense of duty requires a rethinking of the relationship between mankind and other species, one that allows us to value other species for their particular properties as well as for the good they do us (Rolston 1985; Bennett 1986; Sagoff 1986). A second is that we derive much economic benefit from other species, and their continued preservation ensures that we will reap such benefits in the future. Examples abound (Oldfield 1984). The value of plants for medicinal purposes is one example of the economic benefit of preserving species. The International Union for the Conservation of Nature and Natural Resources recently

estimated the worldwide retail value of tropical plants for medicinal uses at $\$ 20$ billion (WWF 1986). The third argument, and perhaps the most critical one, is that ecosystems and the organisms they comprise provide us with services upon which we humans depend for survival, for example, production of oxygen, nitrogen fixation, and breakdown of organic wastes and chemical pollutants, among many others (Pimentel et al. 1980).

Aside from survival value, the services provided by ecosystems are of great economic benefit to society. The benefit, however, tends to be underestimated because the interconnectedness of components of the biosphere is not always recognized. Consider, for example, the ability of soil micro-organisms to fix nitrogen from the atmosphere. Assigning a dollar value to the nitrogen in the soil inadequately accounts for the benefits provided by nitrogen because other, related services, such as better soil erosion control and support of larger or more diverse plant and animal populations, are

also provided (Westman 1977).

The problem with the ecosystemservice argument is that while scientists are sure of the disastrous ecological consequences of causing the dysfunction of a whole trophic level, for example, the producer (plant) level, or the decomposer level, they effectively do not know what the consequen- 
ces of losing some species within a trophic level will be, nor what the threshold level is below which species loss becomes noticeably deleterious to the ecosystem. That such thresholds exist, however, is one of the functional postulates of conservation biology (Soule 1985). In ecosystems where the species have co-existed and evolved together over a long period of time, species are highly dependent upon others for existence. This means that the extinction of one species can result in the loss of many others, and that low numbers of species could be reached quickly. Already nearly 40 percent of the net primary productivity of terrestrial ecosystems is used directly or indirectly by people, flows to different components of the food chain, or is lost because of changes in land use due to human ac-

Net Primary Productivity (NPP): the rate of storage of organic matter in plant tissues in excess of that used up by respiration. NPP is one basis of life for all organisms that directly or indirectly depend upon plants for food. tivities (Vitousek et al. 1986). Further use by us humans will further restrict the amount of energy available to other species that live on Earth. How much more diversion of net primary productivity is possible before disasters result from species loss?

Avolding that unknown disaster threshold is only prudent. Perhaps the following ecosystemas-car analogy will help clarify why. Many benefits are obtained from operating cars, for example, aesthetic benefits when cars are used for Sunday drives in the countryside, or economic benefits when cars are used for transportation by sales representatives. A car can be maintained in good working order and can be expected to last a long time. Alternatively, the maintenance requirements of a car can be ignored, in which case the car is likely to break down quickly at a very inconvenient time (as Murphy's Law would have it).

The necessary repairs are likely to be far more costly than expenses associated with preventive maintenance. You could run a brand new car without an oil change for perhaps 15 thousand miles, whereupon the engine may have to be replaced. To replace the engine might cost
$\$ 2,000$. Five or six oil changes would have cost only $\$ 150$.

Similarly, it is possible to exploit ecosystems and obtain great short-term economic benefits from doing so. However, malfunction of the ecosystem will result. Not all components of the ecosystem may fail at once, but the loss of biological diversity is similar to running a car on less than a full complement of cylinders. Eventually ecosystem performance will be so poor that repairs will be required. And like a malfunctioning car, the ecosystem can then be repaired to good working order.

Actually, probably not. First, the costs of restoration may be too high (Wolf 1987). One example of how costly large-scale restoration can be is provided by the nearly $\$ 600$ billion needed to restore the integrity of natural aquatic ecosystems in the United States (Westman 1977). Or the components with which to make repairs may not be available. An extinct species cannot be replaced, though up to a certain point it might be substituted for because other species may be able to fill the niche of the extinct species. Some substitutions have been successful, and others have not (Ehrlich and Mooney 1983). Worst of all, we "mechanics" may be dead because our life-support system, the environment, has malfunctioned. Obviously, we are not yet at such a harmful level of malNiche: includes the physical space occupied by an organism and the role that an organism plays within an ecosystem. A niche may be occupied by different species in different geographical areas. For example, kangaroos in Australia occupy niches similar to bison and deer in North America

functioning, at

least not on a

large scale. But where the critical level lies is not known. A safer alternative is to prevent further loss of biological diversity and to keep the world's ecosystems operating as well as is currently possible.

We are playing a game of Russian roulette when we decrease biological diversity. How many more economic and other gains are required to make the pulling of the trigger one more time a 
rational decision? Do we have enough economic and other information to make thoughtful decisions with respect to the environment?

We find ourselves flirting with ecological disaster because of a series of small, independently made, but ecologically unfavorable decisions the tyranny of small decisions (Odum 1982). To counteract the trend, we as individuals may have to make a number of small decisions to restore or ensure ecosystem function. That may mean taking a bus to work instead of driving a car, not manicuring some portion of a backyard in order to provide some shelter for birds or other small animals, or donating money to organizations that acquire wildlife habitat, among other measures. However, some needs demand more than our abilities as individuals; these require a statement of goals and the co-ordination of several organizations, within which individual commitments can be more effectual.

A larger view towards maintaining the integrity of the Earth's ecosystems characterizes the World Conservation Strategy (WCS) (IUCN 1980). The WCS has three main objectives: the maintenance of ecological processes and life support systems, the preservation of genetic (biological) diversity, and sustainable use of species and ecosystems, that is, maintaining harvested resources at sustainable levels (Prescott-Allen 1986). The implementation of the WCS, however, depends upon the commitment, in philosophy and in action, of levels of government from national to local throughout the world (Crerar 1986). In Alberta, the Public Advisory Committees to the Environment Council of Alberta are in the process of preparing a draft conservation strategy for the province. The dominant importance of the three WCS objectives previously described is affirmed by their inclusion as the first three objectives, of six, in the Prospectus for an Alberta Conservation Strategy (PAC 1986).

One way to meet the objectives is to maintain tracts of land in a virtually unaltered state, land set aside as nature reserves. Within the context of the WCS, such preserved areas are called in situ reserves (Prescott-Allen 1986). Albertans are in the happy position of having large tracts of Crown land with protected status, such as national and provincial parks, and wilderness areas. Large areas of Crown land that are not intensively partitioned among user groups also exist. Conceivably, more land and water bodies could be added to a reserve system without imposing the sacrifices that would be required if such measures were attempted in many of the overpopulated, developing, and increasingly ecologically impoverished regions of the world. The question, then, becomes this: is there a need for more nature reserves in Alberta?

Reserves for Nature presents some concepts that may help those preparing the Alberta Conservation Strategy to evaluate the ability of the current system of reserves in Alberta to meet the first three strategy goals, and to put together some strategies to ensure that the objectives can be maintained or met in the future. Chapter two of the report describes some tenets of the theory of island biogeography. This theory explains the species diversity and species composition of oceanic islands in terms of island size, age, and isolation. Land-based nature reserves are thought to behave in a similar, though not identical, fashion to oceanic islands, which makes it possible to glean from the theory insights into the design of nature reserves. Chapter three of the report builds upon knowledge of island biogeography to identify some principles for the design of nature reserves.

The theory, however, is developed for ecosystems operating largely in the absence of human interference. Chapter four of the report describes some circumstances under which modification of ecosystems, or modification of human activity, may be required, so that nature reserves can fulfill the three biological objectives of the conservation strategy for Alberta. 


\section{Chapter 2}

\section{BASIC BIOGEOGRAPHY}

\section{How Many Species Can an Island Sustain?}

The theory of island biogeography is based on observations of the composition and diversity of animal populations on island archipelagos. The most fundamental element of the theory is that there exists a mathematical relationship between the number of species on an island and the island's area. Generally, the bigger the island, the more species it will sustain, but the relationship is not a linear (straight line) one. At first, with increasing island area, the number of species rapidly increases. With further increases in area, the number of species gradually reaches a maximum.

This type of mathematical relationship between island species and island area can be expressed as follows:

$$
\mathrm{S}=\mathrm{CA} \mathrm{A}^{2}
$$

where:

$\mathrm{S}=$ the number of species;

$C=$ a constant, the value of which depends on the type of organism under investigation, where the study is taking place, and the unit of area used in the survey:

$A=$ area of the island; and

$z=a$ constant between 0 and 1 that represents the strength of the relation between species number and island area, which can be regarded as a measure of the isolation of the islands. For marine islands, the constant $\mathrm{z}$ commonly assumes a value ranging from 0.20 to 0.35 , averaging close to 0.30 .
Figure 1 illustrates an equation with $\mathrm{C}=9.17$ and $z=0.3161$.

The reader who looks at the number 32 on the $\mathrm{y}$ axis and notes the corresponding $\mathrm{x}$ value, and then does the same thing for the number 64 on the $y$ axis, observes that a tenfold increase in island area results in only a doubling of species number! With higher values of $z$, the area needed to effect similar increases in species number decreases. With lower values of $z$, the area requirements increase. But within the range of $z$ values observed in most studies, clearly, large increases in island area are required to find substantial increases in species number.

The increase in species number with island area results because of the relationship between area and other ecological variables, notably habitat. Generally, the larger the island area the greater will be the diversity of habitat, and more niches will be available for different species to occupy. In addition, each habitat is likely to be more extensive on larger islands, which means that larger populations of each species can exist. Larger populations give species a better chance of survival, for they are not as severely affected by the loss of individuals due to some environmental disturbances or due to impoverishment of genetic variability.

Whether or not the island habitat is packed with many species depends upon the immigration of species from other sources. Over time, the number of species on an island strongly depends upon the rates of immigration and extinction. When the rate of immigration exceeds the rate of extinction. species diversity increases. The theory of island biogeography suggests that the number of species 


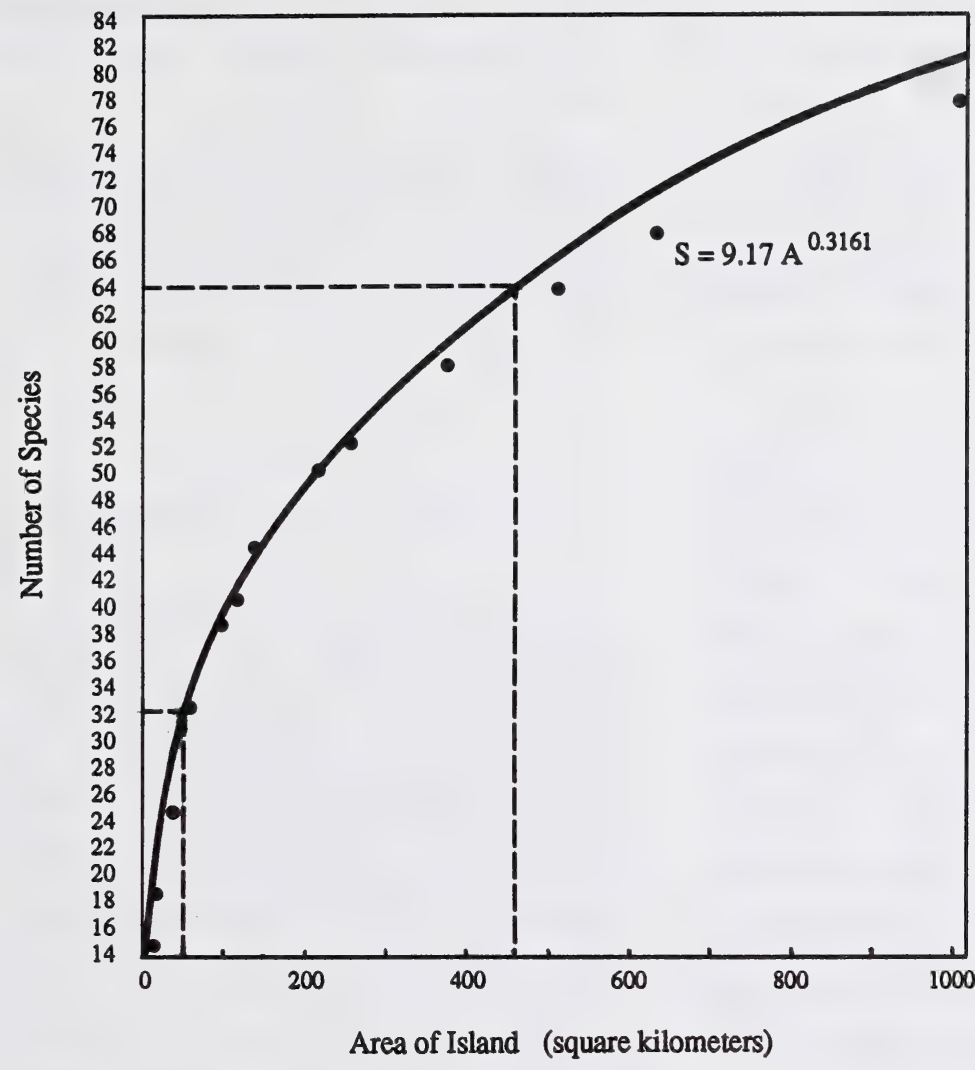

Figure 1. Species and Area

Scattergram and regression line showing the mathematical relationship between the number of species on an island and island area.

will ultimately reach an equilibrium, but the species composition may change radically over time, partly because of species turnover (that is, the extinction of some species and the arrival of new species). In the case of land-bridge islands, the change in species composition may be due to species turnover and to a decrease in species number.

Many oceanic islands were joined to larger land masses during late Pleistocene times, when great quantities of water were locked up in glaciers. About 10,000 years ago, when the glaciers melted and sea levels rose, areas of higher topographic relief became islands. When the landbridge islands first separated, they supported a "species-rich continental" fauna rather than the relatively impoverished fauna they now support. The concept of "relaxation rates" measures the time over which the species diversity will reach the equilibrium level from the initial higher levels of species diversity. The relaxation time varies with original species diversity and area; generally, the greater the original species diversity and island area, the longer the time required to reach equilibrium. To give a rough idea of the effect of area, Diamond (1975) estimated that 7,600 years were required for the bird species diversity on a land-bridge island with an area of 2,040 square kilometers near New Guinea to be red s:ed by 50 percent. A small land-bridge island of 17 square kilometers, created in 1914 as the Panama Canal was flooded, is anticipated to lose 20 percent of its bird species before the island's centennial (Terborgh 1974).

The rate of immigration onto an island depends upon its area and degree of isolation, and species mobility. For species that disperse widely, the probability of finding an island that contains suitable habitat and a vacant niche increases if the island is large and near to the place of emigration. Obviously, species such as flightless birds are severely constrained by even narrow bodies of water. Some species that are capable of dispersing widely, however, will not 
emigrate over even short distances. A gap of a mere 10 meters may be sufficient to prevent some tropical bird species from emigrating from one island to another (MacArthur 1972). Different taxonomic groups vary in their ability to immigrate, and therefore recurrent colonization patterns predicted on the basis of island biogeographic theory will reflect the dispersal capacity of the organisms under investigation. For instance, similarly sized islands equidistant from a mainland are likely to be relatively rich in good dispensers like plants and birds and relatively poor in mammals (Case and Cody 1987). Only at greater distances are plants likely to be poorly represented.

The negative effect of isolation on immigration rates can be mitigated by stepping stones, that is, small islands within the dispersal distance of a species that allow it to move from island to island and ultimately to disperse over great distances.

Island biogeographic theory is more extensive and formalized than the description presented thus far. ${ }^{1}$ However, even from this brief discussion, we can derlve some insights into the way land-based nature reserves operate, for they are thought to be ecological islands.

A nature reserve on a continental land mass is contiguous with surrounding plant and animal communities. When a nature reserve is first designated, it may very well be quite similar to the ecological communities surrounding it, so that the reserve can be thought of as a sample from a larger area. Typically, then, the reserve will contain more species than an island area of equal size, because the reserve is not isolated. As the environment surrounding the protected reserve is altered by human activities, the reserve behaves more like an oceanic island, with some important differences relating to the move towards an equilibrium of species numbers.

First, with the disappearance of surrounding habitat, the source of recolonization for the reserve species disappears. In intensively exploited landscapes, "the appropriate context is that of land-bridge islands in which the source has been removed and only islands remain" (Terborgh 1976, 1029). Second, because the reserve habitats probably will be at least partially occupied by species overflowing from the adjacent disturbed area, immigrants of species typical of the reserve will find it harder to colonize (MacArthur and Wilson 1967). Third, because the habitats surrounding the reserve support competitors, the populations in the reserve will be constantly exposed to pressure of invasion from those competitors, thus suffering from higher rates of extinction than like-sized oceanic islands. In many cases, the reserve will be invaded by species that are distributed widely and do not need the protection of reserves (Pickett and Thompson 1978). Thus, with reduced immigration and increased extinction, large losses of species for which the reserve was initially set aside may be characteristic of nature reserves.

What can be done to minimize the loss of species in reserves? For the past 15 years or so, scientists have used the principles of island biogeography when designing nature reserves, especially land-based ones. The main offerings of the theory are insights with respect to the size and configuration of reserves. Island biogeographic theory, in conjunction with other, mostly biological knowledge, can be used to speculate about the potential of reserves to maintain high biological diversity, and that is the subject of Chapter 3.

1 Readers wanting more detailed coverage of the subject may consult The Theory of Island Blogeography by R.H. MacArthur and E.O. Wilson, or Geographical Ecology by R.H. MacArthur. 
Chapter 3

\section{WHAT THE THEORY TELLS US ABOUT THE DESIGN OF NATURE RESERVES}

\section{To Protect Rare Species or Typical Species?}

Island biogeographic theory does not tell us whether to emphasize the protection of rare or typical species, or systems characterized by high or low biological diversity. All else being equal, the types of sites chosen depend on how closely they fit with the goals, objectives, and abilities of those wishing to set aside sites for preservation. There are many criteria (including area) by which to evaluate the desirability of sites as nature reserves (Smith and Theberge 1986; Margules and Usher 1981). What the study of biogeography does, however, is provide a basis for interpreting and predicting the ecology of nature reserves. It also provides some tools with which to assess the biological characteristics of a site.

One tool involves graphing the number of species and the areas of candidate sites for reserves (Usher 1985). Figure 2, based on hypothetical data, is an illustration of such a plot. The low zvalue is characteristic of land-based ecosystems. Sites close to the line through the data points would be chosen if "typical" sites were desirable. Sites considerably above the regression line would be chosen if biological diversity were the dominant criterion, for example, the site indicated by the arrow. The same data point indicates that, in some cases, smaller sites may contain more species than larger ones. Such sites may be especially desirable because of reduced direct costs and opportunity costs to acquire and maintain them, though management costs may be higher. They may not be the most diverse of all possible sites, but the most diverse among sites of equal area. Sites below the line might not be strong candidates for reserve status because of their low diversity.

When sites are selected for their high biological diversity, care must be taken to ensure that the diversity is a long-term phenomenon and not the result of many transient species. Recent studies in Brazilian jungles, for instance, have shown that clearing around forest islands results in large temporary increases in the numbers and species of birds in the forest island. Soon afterwards many of them died or emigrated (Ola and d'Aulaire 1986).

In these studies, the habitat islands were deliberately created so that island effects could be observed. What happened is probably similar to changes in the species composition of nature reserves that become isolated over longer periods of time. The species diversity is expected to decrease with time. Selection of reserve sites on the basis of a species-area curve, especially if the mathematical fit of the line to the data points is not very good, without taking account of immigration, emigration, extinction, and species composition, would not be satisfactory (Boecklen and Gotelli 1984; Opportunity Cost: the amount of other products or benefits that are forgone or sacrificed to obtain a particular good. For $\theta x-$ ample, society will forgo some environmental benefits when ecosystems are disrupted by a coal mining operation. McCoy 1982. 1983; Reed 1983). High species diversity associated with high habitat diversity would be a 
first clue that the species diversity observed is a longer term phenomenon, and that the site would be especially worth preserving.

Given a choice, looking beyond species to the preservation of ecosystems is preferable. The ecosystem represents a couple of steps above species in the ecological hierarchy, so focusing on ecosystems should allow for the maintenance of ecosystem processes and for the preservation of species diversity. This would allow the first two goals of the World Conservation Strategy to be met simultaneously. A focus on species neither requires nor guarantees the preservation of ecosystem processes (Noss and Harris 1986). Ultimately, too, managing on a species-by-species basis may be too expensive (Norse et al. 1986).

The focus on the ecosystem presumably means the ecosystem with its original component species. Replacement species rarely have the

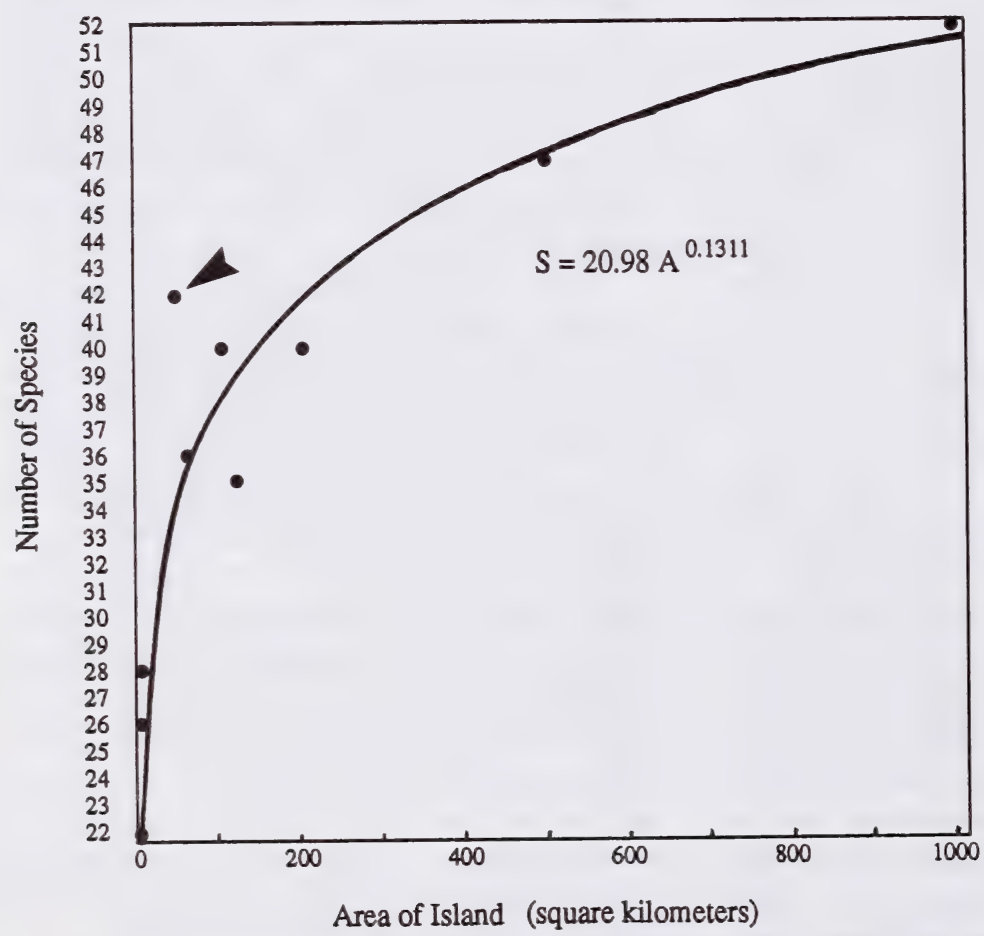

Figure 2. A Species-Area Curve

A species-area curve can be used as a tool to help decide among sites for a nature reserve. same niche as a species lost to the ecosystem. A species like a house sparrow may successfully out compete a bluebird for nesting cavities, but it does not perform the same ecological job as a bluebird. If the introduced species persists, the measure of simple species diversity remains the same, but the reduction in ecosystem functioning argues in favor of maintaining both the ecosystem processes and original component species within reserves. To do so, examples of common habitats, and also the scarcer habitats and the many rare species that naturally occur in ecosystems, should be protected in reserves (Adamus and Clough 1978).

\section{How Large Should Nature Reserves $\mathrm{Be}$ ?}

Notwithstanding sites of especially high diversity, species-area curves like those of Figure 1 and 2, and the theory behind them, suggest that a large reserve houses a greater number of species than a small one. To repeat, large reserves tend to have a greater number of and more extensive habitats, and therefore support more species and larger populations than small reserves, which reduces the probability of species extinction. In sufficiently large areas, disturbances such as a fire caused by lightning may occur, but the overall landscape pattern may be fairly constant over time (Romme and Knight 1982; Noss and Harris 1986). Small reserves, on the contrary, are quite susceptible to destabilization. Only species-area curves drawn for a particular region and type of organism will tell us the appropriate size for 
reserves, but considering viable population sizes for animals characteristic of the ecosystem to be preserved, or for animals specifically targeted for preservation - perhaps the most extinctionprone species (Pickett and Thompson 1978) or those that determine the structure of an ecosystem (Ehrlich and Mooney 1983) - can help to define just how large reserves should be.

In general, a population is subject to four more or less random variations in its own characteristics and in its environment. A minimum viable population, then, is one that can maintain itself under average conditions, and is large enough to endure or adapt to changes in its environment (Shaffer 1981; Vida 1978). Shaffer offers a tentative and arbitrary definition of minimum viable population:

A minimum viable population for any given species in any given habitat is the smallest isolated population having a $99 \%$ chance of remaining extant for 1,000 years despite the foreseeable effects of demographic, environmental, and genetic stochasticity, and natural catastrophes (Shaffer 1981:132).

Just how large would a population have to be in order to be viable?

Some work on mammals provides insight to the answer. Populations in the tens are not enough. For instance, Picton (1979) noted the spontaneous extinction of a population of 20 apparently healthy mountain goats in Montana.

Hudson (1983) cal-

Demographic: pertaining to characteristics of populations such as births, deaths, and population-age distributions, among others. culated a high probability of extinction within 35 years for a population of 14 black rhinoceros

with balanced age and sex distributions. His analysis was based on chance events alone. Shaffer (1981) calculated that a population of 30 to 70 grizzly bears, depending upon habitat size and quality, would have less than a 95 percent chance of surviving for 100 years. From a conservation perspective, those odds are not very good.
Such observations do not mean that quite large populations of animals cannot be built up from small founding populations. They can. But the rebuilt populations often suffer from inbreeding or loss of genetic variability. Recently, for instance, cheetahs have been shown to be genetically depauperate. This may have resulted because the species underwent a severe population reduction about 10,000 to 12,000 years ago and subsequently increased in number slowly, which increases the likelihood of losing different gene types (O'Brien et al. 1986; Cohn 1986). In such cases, there is reason to fear an inability to withstand environmental change.

Assuming ideal conditions, an estimated 50 breeding individuals are needed to guarantee survival in the short term, and 500 are needed to guarantee a long-term future (Norse et al. 1986). Populations in the several hundreds to a few thousands are thought to be necessary to retain enough genetic variation to permit adaptation to changing environmental conditions, and for longterm evolutionary potential (Wilcox 1986; Soule 1985; Shaffer 1981; Vida 1978). Possibly the socalled " $50 / 500$ " rule is not applicable to insects that lay many eggs, for their genetic diversity is

Stochastlc: adjective implying the presence of a random variable or a system operating in a random fashion due to the presence of random variables.

high even though only a few of the eggs result in reproducing adults (Arnold 1980).

If we multiply the habitat requirements of each animal by the minimum viable population sizes of targeted species, we obtain a rough estimate of the order of magnitude of the size of nature reserves. Because of the loss of energy associated with each trophic level, the top carnivores within an ecosystem are often rare and their habitat requirements large. Each bear or cougar, for example, requires several square kilometers of habitat for survival. If we adopt the reasoning that by striving to maintain a viable population of top carnivores then we will be preserving sufficiently large expanses of landscape to maintain whole ecosystems and the diversity within them (the World Bank has recent- 
ly adopted this principle when evaluating the environmental impact of funding proposals (Fitzgerald 1986)), then reserves generally will have to be very large indeed!

Many ecologists believe that reserves have to be at least a few thousand square kilometers in area in order to be effective (e.g., Terborgh 1974; Whitcomb et al. 1976). For example, an estimated 1.2 million hectares are needed to maintain a short-term effective population of 50 grizzly bears, while 12 million hectares are needed for 500 (Norse et al. 1986). East (1981) estimated that reserves in excess of 1 million hectares were needed for large carnivores to be represented by a few hundred individuals in African savanna reserves. Others have suggested that 20 percent or more of the nation's landscape should enjoy some protection as nature reserve when non-reserve areas are intensively used (Helliwell 1975). Each ecological region would need to be represented in a Effective Population: a measure of the actual pool of breeding individuals in a population. The effective population size depends upon age and sex ratios. For example, given 10 individuals of a certain species, two of whom were breeding-age males and eight of whom were females no longer capable of bearing young, the effective population size would be zero. reserve system.

These data are disputable and may not be appropriate everywhere. However, they do suggest that large expanses of reserve land are necessary

\section{Table 1}

\section{Post-Establishment Extinctions and Area of 14 Western North American National Parks}

\begin{tabular}{lllr} 
Park/park assemblage & $\begin{array}{l}\text { No. of post- } \\
\text { establishment } \\
\text { natural } \\
\text { extinctions }\end{array}$ & $\begin{array}{l}\text { No. of post- } \\
\text { establishment } \\
\text { human-influenced } \\
\text { extinctions }{ }^{2}\end{array}$ & $\begin{array}{r}\text { Area } \\
\left(\mathbf{k m}^{2}\right)\end{array}$ \\
\hline Bryce Canyon & 4 & & 144 \\
Lassen Volcanic & 6 & 1 & 426 \\
Zion & 5 & 0 & 583 \\
Crater Lake & 5 & 0 & 641 \\
Manning Provincial & 3 & 0 & 712 \\
Mount Rainier & 7 & 0 & 976 \\
Rocky Mountain & 2 & 0 & 1,049 \\
Yosemite & 3 & 0 & 2,083 \\
Sequola-Kings Canyon & 3 & 1 & 3,389 \\
Olympic & 0 & 3 & 3,628 \\
Glacier-Waterton Lakes & 2 & 1 & 4,627 \\
Grand Canyon & 1 & 0 & 4,931 \\
Grand Teton-Yellowstone & 1 & 1 & 10,328 \\
Kootenay-Banff-Jasper-Yoho & 0 & 0 & 20,736
\end{tabular}

${ }^{1}$ A natural extinction is one not directly related to human disturbance within a park.

${ }^{2} \mathrm{~A}$ human-Influenced extinction is one potentially or directly related to human activities within a park.

Source: Adapted from Newmark 1987. 


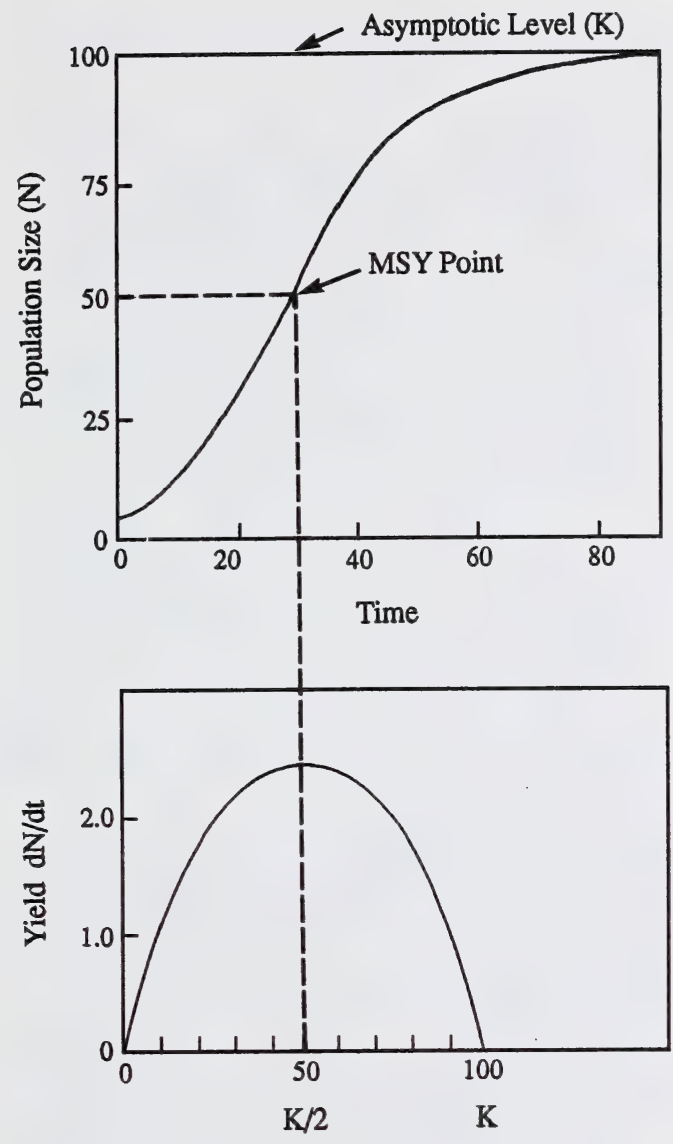

Population Size

Figure 3. Population Growth and Yield

Location of the maximum sustainable yield (MSY) point and asymptotic level $(\mathrm{K})$ for a logistic population growth curve (upper panel) and the sustainable yields for various population levels (lower panel).

to conserve large carnivores and whole ecosystems in a natural state.

How does Alberta stack up against such figures? In a study that extensively assessed the conservation functions of various Alberta government departments, Swinnerton (1984) identified approximately 18 million acres $(7.3$ million hectares), 11 percent of Alberta's land area, which enjoy some protected status. The largest proportion of protected land is in the basically un- touched Green Area rather than the settled White Area. The dedication of sizeable reserves in the Green Area seems to have paid some dividends in terms of keeping species assemblages intact. Newmark (1987), for example, noted that the four mountain parks assemblage in Alberta and British Columbia (Banff-Jasper-Kootenay-Yoho) was the only park or park assemblage he studied among 13 others in western North America that has not suffered a post-establishment mammalian extinction. This area was also the largest of the parks assemblages studied. The other areas have suffered natural post-establishment extinctions in numbers that are well correlated with park size (see Table 1).

Whatever reserve size is decided upon using the criterion of maintaining viable populations of targeted species under "natural" conditions, it may have to be modified upwards if harvesting of populations within the reserve is desirable or cannot be prevented (poaching). Figure 3 is a diagram of population size against time, showing the classic population growth curve where population numbers rise slowly at first, then undergo a period of rapid growth, followed by a levelling off at a higher level. The location marked MSY, maximum sustainable yield, marks the point where the change in yield, though still positive, begins to decrease. The MSY is the level to which managers try to harvest popula-

tions even though Yield: net primary productivity availrevenues over costs able for human use.

may not be maxi-

mized and may not allow the harvesting operation to last indefinitely (Clark 1973; Fife 1971). The extent to which the MSY emphasizes yield rather than the relative ability of a population to survive the forces of natural selection, and the extent to which population size at the MSY varies with the size of the minimum viable population, would define the extent to which reserve size must be altered in order to run a harvesting operation for a long time. For example, typically, minimum viable population exceeds population size corresponding to the MSY, so the reserve size would have to be boosted accordingly. 
In reserves designed to protect top carnivores, harvesting of species upon which the carnivores depend for sustenance would also require an increase in reserve size, in order to ensure that the populations of the harvested species were at viable levels after natural predation and harvesting by humans.

It may not be practical to set aside reserves of thousands of square kilometers or more. There may not be enough suitable land to set aside, or the costs of acquiring and protecting such expanses may be prohibitively high (Adamus and Clough 1978; Terborgh 1974). In Alberta, for instance, there exist few areas of sufficient size to set aside as large reserves in the settled White Area, whereas there is more potential to set aside large, basically untouched areas in the Green Area. In cases where large tracts of land cannot be made available, measures to connect reserves to one another, and to integrate the in-between areas into the reserve system while allowing human activity, are probably necessary. More will be saild of these concepts later in the chapter.

The reader can appreciate differences in the size of potential reserves in the White and Green Areas by examining Appendix 1. The sites identified in the appendix are organized by natural region, and represent only sites within provincial parks and some other areas for which summary information is available. The numbers under the column "weighted size values" are weighted values that take account of both the size of the potential reserve site and the size of the buffer area surrounding it. For the purposes of comparison, the number 10 is used as a reference point. A site with the number 10 beside it indicates a site with an area of 10 square kilometers and a buffer area in excess of 500 square kilometers, a site of 500 square kilometers, or something in between these two extremes, such as a site of 30 square kilometers and a buffer area of 200 square kilometers. Compared to areas considered to be appropriately large by several ecologists (Terborgh 1974, Whitcomb et al. 1976, Norse et al. 1986, and others), these orders of size are not large. Of 45 sites within the White Area, nine $(20 \%)$ had size values of 10 or more. Of 48 sites within the Green Area, 33 (69\%) had size values of 10 or more.

Fortunately, large reserves are definitely not the only ones of value. Small reserves that complement large ones within a multiple reserve system are valuable too. Small reserves tend to assume more importance when the focus of conservation is on species more so than on ecosystems. A combined strategy would offer protection for species and ecological processes over a whole landscape (Kushlan 1979; Noss 1983).

As a starting proposition, even small amounts of land set aside as nature reserves are better than none. Preserving some species, including the "weedy" ones such as starlings and house sparrows, or common native species such as cowbirds, which are relatively more abundant in small reserves than large ones, is better than creating an ecological desert. To give an idea of the small scales possible, some bird species will nest in areas as small as one square meter, though the probability of nest establishment increases with increasing area. In British rural areas, reserves of 100 hectares or more were recommended by Moore and Hooper (1975). Kitchener et al. (1982) identified the value of a reserve as small as 81 hectares in the Australian wheatbelt, though they recognized the need for much larger reserves to adequately represent flora and fauna on a subregional and regional basis.

In cases where there is little overlap in species composition between areas, it may be preferable to establish many small reserves rather than few large ones, assuming the total area under both conditions to be the same (Usher 1985; Higgs and Usher 1980; Gilpin and Diamond 1980). There is a tradeoff: higher (initial) species diversity and back-up capability in the event of local catastrophe (Simberloff and Abele 1976), for the ability of a large reserve to support natural mechanisms that maintain ecological processes in the reserve. Although the species diversity at the time of demarcation of the small reserves may be higher than that of larger reserves, if smaller 
reserves do in fact suffer from higher species extinction rates than large ones, it would be dangerous to rely on smaller reserves as the mainstay of a conservation strategy (Soule and Simberloff 1986). Small animals (for example, insects) and plants, by virtue of the limited area required to maintain minimum viable populations, are more likely to be accommodated in small reserves (Simberloff and Gotelli 1984; McClanahan 1986; Pyle et al. 1981; Arnold 1980).

In general, small reserves are practical for purposes such as preservation of organisms that survive in small areas (often endemic species), preservation of unique microhabitats, or provision of "stepping stones" between larger reserves, and local education and recreation

benefits (Whitcomb

Endemic: naturally occurring in defined geographic areas. et al. 1976; Terborgh 1974; Robinson 1986). Small reserves can also help to preserve species having little dispersal and colonization ability, and species with colonial nesting habits (Terborgh 1974; Helliwell 1976). Species whose natural habitats can no longer support critical population levels (Kushlan 1979) or competitive species that cannot co-exist in a single reserve (Diamond 1975,1976 ) also benefit from small reserves.

Relatively small areas are also valuable as staging, resting, or destination areas for migratory birds, especially shorebirds. Though the birds may breed over vast expanses of land, they often concentrate in small areas during migration, or at destination points. For example, at any one time, up to 80 percent of the North American population of red knots may congregate in Delaware Bay in the eastern United States (Myers et al. 1987). Locally, Beaverhill Lake east of Edmonton is renowned for the waterfowl and other birds that concentrate there during migrations. The significance of Beaverhill Lake as an important wetland is reflected in its recent designation as a Ramsar ${ }^{1}$ site.
For migratory species, protection of large or small reserves in Alberta is of diminished importance if reserves are not provided in locations where the species rest or overwinter. For example, if habitat within the Mississippi Delta were destroyed, fewer prairie wetlands would be needed for duck production, though other benefits from wetlands would still argue for wetland maintenance. For migratory species, the cooperation of and communication among many jurisdictions is required, though not always easy to attain. The recently launched North American Waterfowl Management Plan, to which Alberta is a signatory, is an example of international cooperation to preserve waterfowl populations (Canadian Wildlife Service and U.S. Fish and Wildlife Service 1986). This level of co-operation is required for other migratory species too, for example, recent efforts by Mexico to protect the Monarch butterfly throughout its range in the wake of its recent establishment of wintering reserves for this insect (Nagano and Freese 1987; McLaren 1987).

Indeed, such co-operation is required for many different species and touches upon international economic concerns. The destruction of central American dry forests and Brazilian rain forests for pastureland, so that cheap beef is available for the fast-food industry, or the destruction of marginal lands for food-growing purposes in some developing countries, while higher capability land is used for growing cash crops to pay off foreign debts, are matters of international economics that bear upon the ability to preserve ecosystems and species. The issue is too large to discuss in this report, but, plainly, large-scale conservation requires co-operation from everyone, on economics and other issues.

\section{How Should Reserves Be Arranged?}

Small reserves located near large reserves may have similar levels of species diversity. This can

1 The Ramsar Convention, named after the Iranian city in which it was adopted, is an international treaty to conserve wetlands, especially those important to waterfowl. 
be expected from what we know about island biogeography. Two principles are worth repeating:

1) on small reserves the species extinction rate is higher than on large reserves, meaning that species different from those originally in the reserve may be responsible for maintaining the diversity level, and

2) recolonization only occurs if small reserves effectively are connected with large ones (Soule 1985).

Isolation, however, is a relative concept, and depends upon the physiological and psychological needs of different species. The potentially small distances that can effectively isolate habitats have already been commented upon. For land-based reserves, barriers are apt to take on a different nature, for example, highways. One study determined that divided highways with clearances of over 90 meters may have the barrier effect for small forest mammals of a water body twice as wide (Oxley et al. 1974). Agricultural fields can also act as habitat barriers (Mader 1984). In view of the significance of barriers to colonization, reserves, especially small ones, should be arranged to minimize the effects of isolation.

Arranging the smaller reserves as close to one another as possible is perhaps the most obvious means of minimizing the effects of isolation. If there are a number of separate reserves, they should be arranged in a triangular or circular pattern rather than stringing them out in linear fashion. Another way to overcome isolation is to use corridors to connect separate reserves.

To be most effective as conduits between isolated reserves, the corridors should be sufficiently wide. The outer regions of natural areas, for example, a woodland, have different microclimatic characteristics than the interior. Differences in species composition and abundance between the two zones result, and are described as an "edge effect." To ensure the movement of "interior species" between reserves, the corridors should be wide enough to include interior micro climates (Forman and Godron 1981). Studies have determined that corridors need to be at least 60 to 100 meters wide to accommodate the movement of interior species of birds and trees (Noss 1983).

The existence of an edge effect is also part of the reason for thinking that reserves should be roughly circular in shape, where a choice is possible. A circular shape maximizes the interior-toedge ratio and dispersal distances within the reserve are minimized (Schonewald-Cox and Bayless 1986). These considerations are of greater significance for small reserves than for large ones.

Circular reserves, however, are not to be universally preferred. When extinction rates within reserves are relatively less dependent on shape than are immigration rates, other shapes may be optimal (Game 1980). Rapoport et al. (1986) demonstrated the (initial) conservation value of an irregularly shaped reserve that takes account of the spatial distribution of species to be protected.

While single corridors are better than none, a network of corridors is better still because alternative pathways are available. Redundancy in the corridor is important "for animal foraging efficiency, predator avoidance, and minimizing the barrier or isolating effect of a local disturbance or break in a corridor link" (Forman and Godron 1981: 737). Maximizing connections between reserves also would enhance conservation across whole landscapes rather than confined areas (Noss and Harris 1986). Hedgerows fit nicely into the concept of a network. Unfortunately, the conservation and economic benefits that hedgerows confer are lost when they are cleared to minimize the cost of working farm flelds with large machinery (Forman and Baudry 1984), or when they might be adversely affected by farm operations such as herbicide applications.

The above principles of the design of nature reserves are summarized in Figure 4 . In configuration A, large reserves are thought to be better than small ones; in $\mathrm{B}$, a large, contiguous 


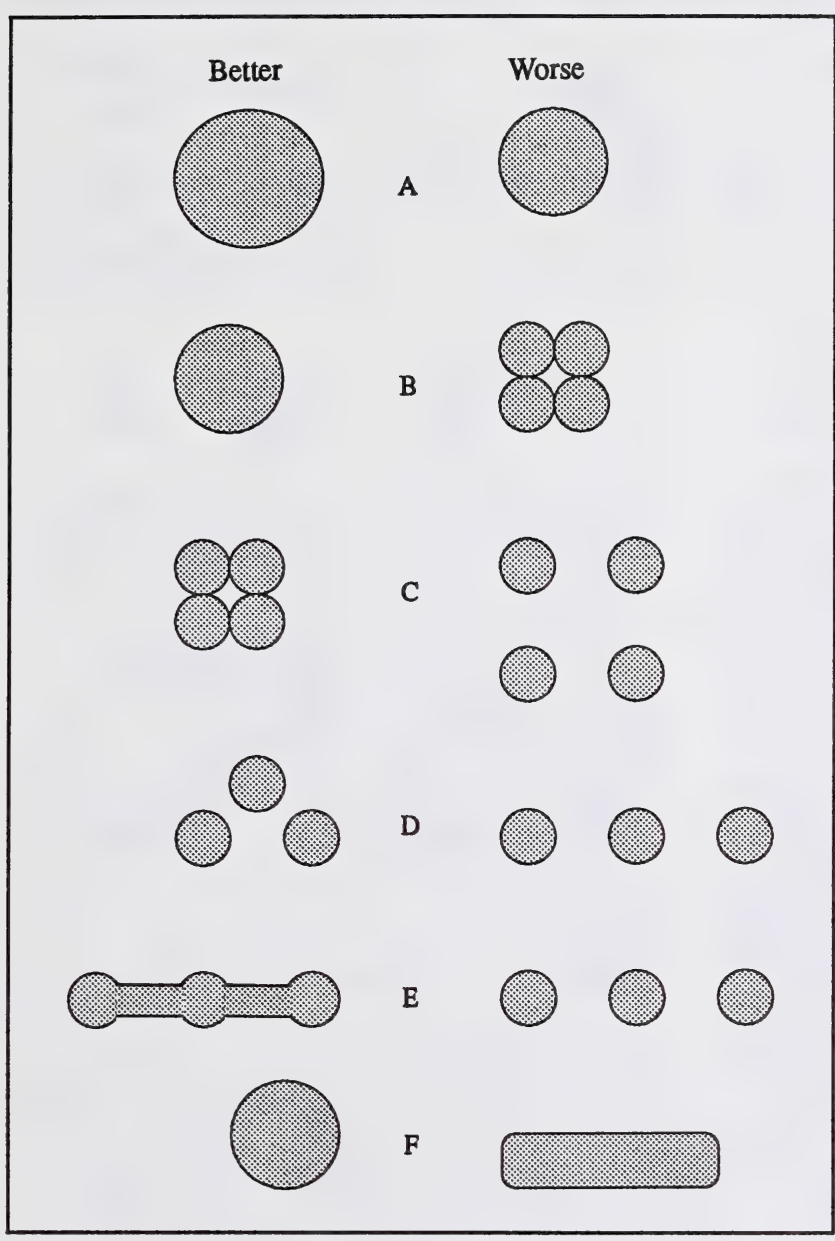

Figure 4. Principles by Which to Design Nature Reserves

Suggested geometric principles, derived from studies of island biogeography, for the design of nature reserves. In each of the six cases labelled $A$ to $F$, species extinction rates will be lower for the reserve design on the left than for the reserve design on the right.

Source: Diamond 1975:143.

reserve is better than several small ones, and so on. A simple demonstration of the added level of complexity presented in real-world situations is lllustrated in Figure 5, showing reserve design over four ecological zones. The soundness of the arrangement of reserves is thought to improve from diagrams $A$ to $F$. Configuration $A$ is insuffcient because conservation is not practiced in two of the ecological zones even though the reserve is large. Configuration $B$ is insufficient because no reserve is likely large enough to sustain acceptable populations of rare species. Configurations $C$ and D represent improvements, but some isolation effects may be evident in the smaller reserves. Configurations $\mathrm{E}$ and $\mathrm{F}$ are best because they offer minimal fragmentation and cover all four ecological zones. Such reserves also may be easier to manage than a larger number of small areas (Helliwell 1976).

Figure 5, illustrating the placement of reserves within an area containing four ecological zones, points to a troublesome problem - climatic change. A climatic warming due to a "greenhouse effect" has been widely predicted by scientists. If the warming were to take place over many hundreds of years, then plants and the animals dependent on them could evolve morphological or behavioral changes that would allow them to live under a different climatic regime. Or plants and animals could shift their distributions with the shifts in climate. However, significant warming could occur in only a couple of hundred years, in which time adaptation or migration by many species is not likely. Are there reserve strategles that might be adopted to minimize the adverse ecological effects of climatic warming?

Peters and Darling (1985) considered that question and offered some suggestions. Locating reserves in areas of topographical relief, for example, in mountainous areas, where altitudinal shifts in vegetation probably would occur with climatic warming, would mean that suitable habitat for many species could be maintained. Concelvably, however, the amount of habitat that is available would be reduced because of the decrease in surface area progressing 
from the base to the peak of a mountain, and mountain populations could become isolated from one another. Where reserves in the northern hemisphere are being set aside primarily for selected species, locating reserves near to the northern limit of a species' range is sensible. A danger of locating reserves near range limits is that shorter term trend reversals could place species at risk. Flexible zoning around reserves would preserve the option to shift boundaries when necessary. For instance, pasture land might be retained to trade for reserve land in the face of climatic shifts.

The concept of multiple-use-modules, or MUMs (Harris 1984; Noss and Harris 1986), not unlike the Biosphere Reserve concept (Batisse 1986; Conservation Foundation 1987), also might provide some flexdbllity under changing climate conditions. MUMs consist of well-defined and protected areas surrounded by buffer zones in which appropriate types and scale of human use are permitted. Ideally, the amount of human use allowed would decrease as one gets closer to the protected area. The buffer zones would be connected into a network that enhances biological dispersal and perpetuates natural disturbance and recovery patterns in ecosystems (Noss and Harris 1986). Kananaskis Country, which contains the Plateau Mountain Natural Area and the Sheep River Sanctuary, is an example that approaches the concept of a MUM in Alberta.

Siting reserves to maximize the en-

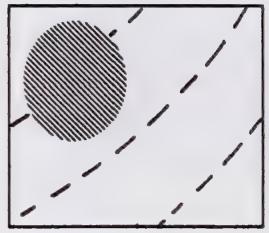

A

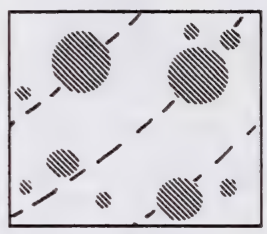

C

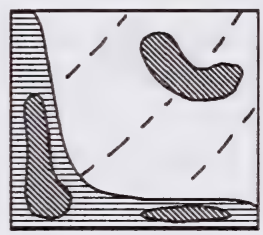

E

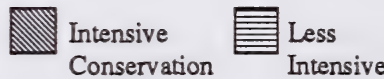

$\begin{array}{ll}\text { Intensive } & \text { Less } \\ \text { Conservation } & \text { Intensive }\end{array}$

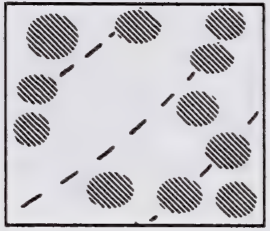

B

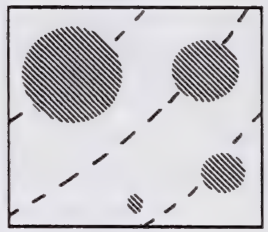

D

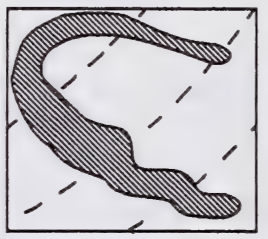

F No Conservation

Figure 5. Nature Reserves and Ecological Communities

A. Single large nature conservation area, overlapping two ecological "zones." B. Several small conservation areas, occurring in all four ecological zones. C. Mixture of small and medium-sized conservation areas. D. Fewer, larger sized conservation areas than in C. E. Similar to D, but with some areas of less intensive nature conservation "linking" areas of more intensive conservation. F. Single nature conservation area straddling all four ecological zones.

Source: Helliwell 1976:257. vironmental benefits when faced with complications such as climatic shifts, ecological zones with different types of organisms, and opportunity costs for maintaining the reserves in "undeveloped" conditions, among others, requires more background than biogeographic theory alone can provide. Theory does not provide all the answers. What theory does, however, is offer some guidelines we can use to assess the merits of potential reserve sites and to organize a system of reserves. Failure to apply the principles may result in failure of the reserves to achieve the objectives set for them. The circumstances under which the basic principles of reserve design or maintenance may be compromised are discussed in the next section of the report. 


\section{Chapter 4}

\section{HUMAN ACTIVITY AND NATURE RESERVES}

Nature reserves are a construct of human activity, but their subsequent integrity can be destroyed or at least strongly influenced by the activities of persons within and surrounding the reserves.

Reserves or parks can be set aside to accomplish one or several objectives. They may, for instance, be designed strictly as nature reserves or they may also attempt to accommodate recreation and tourism, and plant and animal harvesting, among others. Often, however, there is confusion or dispute with respect to the objectives established for an area and whether or not the objectives are being met, given the uses permitted within the reserve.

Recently, for example, the effects of cattle grazing and haying on the conservation of wildlife in national wildlife refuges in the United States were studied. When grazing or haying are carefully controlled and tallored to wildlife habitat requirements, some species may benefit. However, for most wildlife, controlled grazing was either not beneficial or was detrimental. Overgrazing of habitats near water, wildlife mortality due to collisions with cattle fences, and mowing of bird habitat during the breeding season were especially noted. In the United States, other recreational and commercial uses can also be made of national wildlife refuges, but the effects of cattle grazing and haying alone appear to conflict with the high priority assigned to wildlife conservation for the refuges (Strassman 1987). In such circumstances, multiple-use management results in a wide gap between the benefits promised and the benefits actually provided (Lennartz 1979).
In Alberta, use of protected areas for livestock has not always complemented the goals of wildlife conservation either. For example, prior to the preparation of an Integrated Management Plan for Beaverhill Lake, use of wet habitats in the sanctuary by livestock compromised the value of the habitat to a variety of game and non-game animals. Within a block of land near Brooks known as the Antelope Creek Habitat Development Area, which was recently acquired by the provincial government in association with other wildlife organizations or agencies for wildlife and recreational use, some controlled grazing will be allowed. TIme and study will provide Albertans with an assessment of the compatibility of ranching and wildlife conservation in that particular block of land.

Grazing or hunting for management purposes are permitted activities in ecological reserves, according to the Ecological Reserves Act. Grazing is used to mimic natural grazing regimes and hunting is used to control animal populations that exceed carrying capacity. None of these activities is allowed in the reserves established thus far, but grazing would be allowed in the Hand Hills and Wainwright ecological reserves, which will be established early in 1988. Hunting is being considered for the Upper Bob Creek area, which is under review for establishment as an ecological reserve. In all cases, whether grazing or hunting is allowed is decided on a site-by-site basis. Is wildlife conservation enhanced by allowing activities like grazing or hunting in ecological reserves established by the Province? Consider the 
following information on management of nature reserves.

Zoning is often seen as a means to balance the demands placed by various user groups on the resources within a reserve (and also resources outside it). Many people think of zoning as defining specific land-use activities that will be allowed in certain areas. Within a particular zone, the extent of certain activities might be defined and allocated by a variety of means (including lotterles) when demand for such uses exceeds carrying capacity (Walther 1986; Kuss and Morgan 1986; Yapp and Barrow 1979; Cullen 1985). But resource managers often take a different view of the concept of zoning. The zones on zoning maps, for instance, are often viewed as information that defines goals to be met in the long run, within which flexibility in activities allowed is possible (Walther 1986).

A fundamental difference in philosophy with respect to the objectives of zoning and the means to achieve those objectives, for instance, was behind the public controversy that recently surrounded Shell Canada's application to drill for natural gas in the South Castle area of the province. The Government of Alberta's position was that drilling within a Prime Protection area should be accommodated if environmental safeguards were in place; wilderness advocates felt that exploration for natural gas should not be allowed in zones having high wilderness value. A lesson to be gained from such differences of interpretation is - in a variation of a simple principle for dealing with difficult decisions described by the Public Advisory Committees: "make sure you know the extent of your agreement before you begin disagreeing" (PAC 1986:11) - that a common understanding of terminology is required before the use of zoning or any other device can be used to effect the objectives of nature reserves.

Large reserves may be able to accommodate a variety of human activities, but it is unlikely that small ones will have the resiliency to absorb the ecological stresses imposed by human activities. Within large reserves, human access may have to be restricted in certain areas, for example, habitats used by species susceptible to immoderate human presence. The remaining reserve area could constitute a kind of buffer zone where human activities, though not necessarily a full range of them, are allowed (Polunin and Eidsvik 1979; Eidsvik 1980; Yapp and Barrow 1979). With varying degrees of success, such restrictions on human activity are found and accepted within the major national and provincial parks in Alberta.

A thornier question probably revolves around the degree of management that should be allowed within reserves, not whether or not there should be management. Notably in smaller reserves that have been established to maintain populations of one or a few related species, management of the habitat may be required. A strong case for active management can be made where ecological succession threatens habitat that supports endemic species, or that provides a focus for life-support functions such as breeding. Timing management practices with the biology of key species is important. It is in larger reserves, where even fairly large-scale disturbances might affect only a small fraction of the total landscape, that leaving the ecosystems to their own devices might best be entertained. Large, essentially unmanaged areas offer the best prospects for longterm maintenance of ecosystem processes and integrity (Noss 1983; Lewin 1986). In Yellowstone National Park, for example, the fire management policy is to allow lightning-caused fires to burn without interference provided human life, property, or other values are not threatened (Romme and Knight 1982). Management through reliance on natural ecosystem processes can also be expected in Alberta parks (Alberta Department of Recreation and Parks 1986). But, in other cases, the values inherent in even large reserves may depend upon human management for maintenance (Medwecka-Kornas 1977; Chase 1983).

The unwanted introduction of exotics might be one circumstance where intervention is warranted (DeRoy 1987; Moore et al. 1986). Another circumstance would be animal populations that are too large to be sustained by food resources 
within a reserve. (This could be a reflection of an undersized reserve.) The excess animals from reserves, for instance, could be sold to private landowners so that the animals might be farmed. To a limited extent, this already occurs in Alberta. Plains bison (a non-game species in Alberta) that exceed the carrying capacity of Elk Island $\mathrm{Na}$ tional Park are auctioned to persons wishing to build up herds for meat production and other purposes.

Under some circumstances, game farms or ranches could be a source of stock for the reintroduction of threatened species into the wild, as is the case for Nile crocodiles in Africa (Blake and Loveridge 1975); though the programs differ from the concept of game farms per se, swift foxes and peregrine falcons, for example, have been captive-reared in Alberta for release into the wild. The concept of game farms or ranches, however, is a controversial one in Alberta, involving questions of illegal trade in meat and animal parts, whether adequate markets exist, disease and hybridization in attempts to breed for marketable meat quality, and tolerance for competitors or predators of the game species, among other concerns (Renecker and Kozak 1986; Hudson 1984, 1986; Geist 1985).

There are alternatives to selling excess animals when populations exceed carrying capacity. As in some African reserves, the excess large herbivores can be slaughtered and used for food or other products (Younghusband and Myers 1986; Abel and Blalkie 1986). Previously this was the case for the plains bison of Elk Island National Park. Or excess herbivores could be killed and their remains left in remote areas of the reserve to keep populations of rare carnivores such as grizzly bears from reaching precariously low levels (Chase 1983). Surplus animals could be made available for recreational hunting, for example, as is the case for elk in Cypress Hills Provincial Park. Or the animals could be transplanted to establish or buttress populations elsewhere. The alternatives are many. Behind the choices, however, must be the realization that, in these days, despite our wishes to have reserves in as natural a state as possible, management is required so that a semblance of "naturalness" can be maintained within reserves (Hardin 1983; Chase 1983; Kushlan 1979). Unfortunately, sometimes because no alternatives exist, we are managing without either knowing what constitutes "naturalness" or how ecosystems work (Bonnicksen and Stone 1985; Race 1985; Lewin 1986).

The degree of manipulation required is not just a function of reserve size. It is also a function of isolation. Ideally, the land between reserves would not be altered so radically that it became a type of ecological desert compared to its natural capabilities. This ideal appears to be less the case with each passing day.

As the land surrounding reserves becomes more unlike the land within them, and corridors between reserves become fewer, the benign neglect approach to management - one characterized by the absence of either destructive or supportive human intervention - becomes less defensible. Under such circumstances, in order to preserve species diversity and genetic variation, large numbers of animals may have to be transported between reserves, where duplicate populations exist (Soule et al. 1979; Hudson 1983). Migration is a key element of long-term conservation strategies based on several small reserves (Boecklen 1986). Animals from game farms or ranches might serve as another source of stock. So might zoos, except that space and cost considerations make it impractical for zoos to be a source of stock for the many species that are forecast to be endangered (Pinder and Barkham 1978; Foose 1986), and loss of adaptive behavioral traits and immuno resistance to disease may ill equip released animals for coping with a natural environment (May and Lyles 1987). There are risks associated with both the benign neglect and the active intervention approaches to the management of rare or endangered species. Scientific, financial, and political information have to be weighed together in order to find the best solutions to the management decisions before us (Maguire 1986). 
In cases where nature reserves depend upon contiguous areas for critical environmental processes, active intervention within the reserve is required when the contiguous areas are altered. A particularly good example of this is provided by the wildlife management measures required in Everglades National Park in Florida due to alterations in the park's hydrological regime resulting from developments outside the park boundaries (Kushlan 1979, 1987; Odum 1982). Fortunately, in the Everglades example, steps are being taken to restore the natural water flow patterns (Kahn 1986). The history of disruption of the water flow of Everglades National Park illustrates the desirability of (1) buffer zones around reserve areas, and (2) controlling activities within the buffer zones in order to maintain the ecological integrity of the reserve area.

It is not as feasible to control developments that occur well outside a buffer zone. Atmospheric contaminants are thought to be the main external threat to national park ecosystems in the United States (Stottlemyer 1987). Recently, the Commission on National Parks and Protected Areas placed Canada's Forillon National Park in the Gaspe region of Quebec on its list of threatened protected areas because of the effect of air pollution and acid rain on the park's lakes and forests (IUCN Bulletin October/December 1986). Another external threat is water management activities, for example, dam construction (Johnson and Carothers 1987). Concerns about the impact of British Columbia's Bennett Dam on the ecology of Wood Buffalo National Park might be a similar analogy for Alberta.

What, then, of the activities that take place outside the reserves? Should industries that depend upon naturally occurring raw materials establish and maintain ecosystems as potential product banks (Eidsvik 1980)? What about requiring projects that modify ecosystems to provide compensation by strengthening or augmenting the nearest protected tract (Goodland 1980)? Allowing only activities that are compatible with the ecosystem processes within the reserve, or those that do not isolate the reserve ecologically, would seem to make best sense. For instance, in the Brazilian rain forest, planting perennial tree crops is probably a better ecological and macro-economic alternative than trying to convert the rain forest into cropland or cattle pasture (Goodland 1980). In Alberta, reserves that are predominantly forest-covered might be surrounded by buffer zones in which sustained-yield forestry is practiced. Harris (1984) has proposed a system of long-rotation cuts based on biogeographical principles that might be considered. In other areas characteristically covered by native grasses, ranching on the land surrounding a reserve would be more appropriate. But, for example, do the hunting of grizzly bears near Waterton National Park, or trapping them in the nearby Poll Haven area for transplanting elsewhere because of livestock predation, make sense as activities compatible with the ecological processes of the reserve system in the area?

In some places, it is clear that the security of reserves is only assured if people's livelihoods are assured (Myers 1986; Abel and Blaikie 1986). Otherwise, there is a tendency to look upon natural areas as empty areas and demand their use for food, energy, and space (Eidsvik 1980). Livelihoods are dependent upon a complex interplay of many variables, which may be nearly impossible to control. Recently, for example, the Corcovado National Park in Costa Rica was invaded by somewhere between 1,000 and 3,000 gold miners and their families. Many of the miners had worked previously on banana plantations, but turned to gold mining when world banana prices fell and plantation owners closed down their operations (Tangley 1986; Buchanan 1985). The pressures that are destructive to nature reserves are most keenly felt in the developing and over-populated countries of the world. In such countries, recognizing people's traditional roles in ecosystems and integrating parks into a rural development policy may be the only way to save natural areas (Abel and Blaikie 1986; Lusigi 1982; The Conservation Foundation 1987). Native use of wildlife resources in the newly created Polar Bear Pass National Wildlife Area on Bathurst Is- 
land; hunting, fishing, and trapping rights for Cree Indians on 3 million acres of Wood Buffalo National Park; and duck hunting within Point Pelee National Park are examples of this type of use of parks in Canada. To what degree are such uses essential to the protection of reserves in $\mathrm{Al}$ berta?

Ultimately, the maintenance of nature reserves, and the preservation of ecosystem processes and biological diversity, depend upon not exceeding the human carrying capacity of the earth, which basically is a function of population numbers and per capita consumption of resources (Hardin 1986; Catton 1987). Under a scenario of having to use lower and lower grades of raw materials, merely levelling off consumer demands may not avert imbalances of demand and supply of resources, because proportionally more production is being used to extract raw materials than to produce goods to meet demand (Hanson 1977). This latter insight must not be lost in countries, mostly developed ones, that are not characterized by very high and growing populations but have high per capita consumption rates, and certainly not in developing ones that aspire to higher consumption of materials and have rapidly increasing populations.

There are hopeful signs that the consumption of basic materials is levelling off or declining. at least in developed countries (Larson et al. 1986). Part of the reduction in the flow of materials and energy in the economy can be ascribed to the recovery and recycling of materials. More such attempts to link the economy with the environment may be needed in the future to avoid the high costs of pollution control of questionable efficacy (Gilliland 1984). More significantly, recycling, along with conservation and basing development goals on the long-term availability of renewable resources, appears to be a hallmark of a viable and sustainable future (Bossel 1987).

We in Alberta are quite fortunate in having a large land base and only a moderately sized population. Pressures for grazing, oil and gas extraction, and recreational use of our reserves and parks have been persistent, but not intense. The threat that Albertans will consume all the goods they are capable of producing seems quite small over the next few decades. However, there are two ways to sink the metaphorical "lifeboat" - to export goods and to import people (Hardin 1974). Attempting to supply the world's demand for the goods we produce may be of economic benefit when Alberta enjoys a natural advantage in production, but it can also result in more demands on our reserves for the resources they contain. Should we jeopardize our nature reserves by extracting raw materials from them to temporarily sustain the economy? Immigration of persons into Alberta at levels that might challenge the integrity of current nature reserves, under recent amendments to the Canadian Constitution, will be a provincially controlled decision. From the perspective of environmental conservation, some immigration might be beneficial, for example, if immigration were to relieve the pressure on the environment in the countries of origin. Ultimately, however, the countries of origin have the responsibility to stabilize their populations at levels commensurate with their resources. Otherwise, the reserves and the environments in both the source and receiving areas will be jeopardized.

To recapitulate, nature reserves depend upon human efforts for their creation and maintenance. In most cases, letting natural forces shape the future of nature reserves is desirable, but to be dogmatic about this principle would be unwise. The nature and extent of human intervention required depends upon the size and isolation of reserves. Generally, more intervention is required with small reserves, and with reserves that are isolated from each other, than with large reserves or reserves connected to form a network. Intervention also is required when the ecological processes upon which a reserve depends, such as a water supply, are altered.

Planning activities outside the reserve that are compatible with the objectives of the reserve would avoid the need for intervention. However, the role of nature reserves also must be considered in relation to, and be integrated with, 
overall human welfare. Aside from the great welfare benefit provided by maintenance of ecosystem processes, the resources of natural areas can be used for direct human benefit. The grave risk of doing so is that the reserves will lose their protected status and value as human populations and consumption of materials increase. Some of Canada's national parks and park reserves may already be compromised by activities such as plant and animal harvesting, motorized access, and tourism facilities, among others, allowed within or near park boundaries (Struzik 1986). The ultimate human activity needed to maintain the integrity of nature reserves is restraint of our numbers and our material consumption. Without restraint, reserves will only delay, not prevent, the arrival of the types of ecological failure referred to in the introduction of this paper. 


\section{Chapter 5}

\section{CONCLUDING REMARKS}

A system of nature reserves may be required in order to meet the first three objectives of the Alberta Conservation Strategy, which is being prepared by the Public Advisory Committees to the Environment Council of Alberta. In this report, Reserves for Nature, insights that island biogeographic theory provides with respect to the size and organization of nature reserves have been developed. With these principles, it may be possible to assess Alberta's needs for reserves and the adequacy of an already substantial reserve system.

Not all of the implications and applications of island biogeography have been explored. The discussion has focused on the basics as they apply to land-based reserves in the countryside. But, like any theory, the principles should be demonstrable and useful under varied conditions. Davis and Glick (1978), for instance, demonstrated the utility of the theory in the study of urban ecosystems; cities could be made much more attractive as nature reserves (Kelcey 1975. 1978; Vilkitis 1978; Williamson and DeGraaf 1981). Goeden (1979) did the same for archipelagos of coral reefs; the theory may also prove to be useful in explaining the success, or lack thereof, of artificial reefs being constructed in the ocean (Weisburd 1986). Different nuances of the theory may be highlighted with each case, but the basics probably apply in most of them.

The basics of island biogeographic theory are not answers. They provide a plausible basis for understanding processes that affect species within reserves and provide guidelines to answers. A good mathematical fit between the number of species and area may indicate that species are distributed according to the principles of island biogeographic theory, but it will not identify which areas should be chosen as nature reserves. The latter is a decision that is based on island biogeography and other considerations.

Much scientific work suggests that large reserves are needed to adequately protect the ecosystem processes and biological diversity of the province. The general relationship between species number and area, the concept of minimum viable population, and the needs of "interior" species support the case for large reserves. The limits to the effect that individuals can have on ecosystem preservation are thus defined, for most Albertans do not have the resources to fund adequately sized reserves. Only governments are big enough to preserve areas of adequate size. Individuals and organizations, however, are capable of influencing government to set aside large reserves.

Small reserves are also important, especially for the protection of species and different gene pools of plants and smaller animals and where there is not a lot of overlap of species between candidate sites. Individuals normally have a more direct effect in the establishment of small reserves. In the maxim "think globally and act locally," there is wisdom. Certainly, to think about solving the world's environmental problems can be discouraging, whereas local efforts are easier to manage (Tangley 1986). Practical considerations, such as avallability of sites and cost, virtually dictate that small reserves be combined with large ones to provide comprehensive coverage of a region's plants and animals. 
With the passage of time, as opportunities for creating new reserves decrease, greater emphasis will have to be put on development in surrounding areas that complement the goals of nature reserves.

There is much that most individuals can do to advance biological conservation. Homeowners can make their yards more attractive for conserving wildlife (Beebee 1979; Owen 1976); farmers can maintain hedgerows alongside their fields, and can participate in habitat development programs, for example, Alberta's Buck for Wildlife program. On their own and as members of local organizations, individuals have made significant contributions to the preservation of biological diversity, often through small reserves to maintain populations of rare plants or animals. A recent publication by the U.S. Congress, Office of Technology Assessment (1986) describes many such efforts in the United States. These smaller reserves also may be very useful as corridors or stepping stones between large reserves. Conceivably, if enough persons were to make similar small efforts, the system of the small reserves would assume a character that would make achievement of the objectives of the Alberta Conservation Strategy a closer reality.

In view of the urgency surrounding the number and placement of nature reserves in many parts of the world, the decisions often have to be made without adequate information. Unfortunately, a knowledge vacuum exists even for the straightforward process of constructing speciesarea curves, because many organisms that are crucial to the functioning of ecosystems have yet to be identified (Wilson 1985). As in many other parts of the world, decisions about the design of nature reserves in Alberta are likely to continue to be a mixture of science and art.

The scale and type of nature reserves that should be established in Alberta depend upon the type of future the people of the province want for themselves and their children. A system of reserves that incorporates an ecological margin of safety will require a sense of ownership by Albertans, else the reserves will be seen as wasted resources. A thoughtful blending of ecosystem goals with broader societal goals such as economic development is essential to the development of ownership. The art of communication, consensus, and co-operation among different societal interests is required to determine the approprlate scale for reserves in the province. To forge the links among those interests is what the Alberta Conservation Strategy will be trying to accomplish. Forging the links will be greatly assisted by your participation in the development of the Alberta Conservation Strategy. 


\section{APPENDIX 1}

\section{POTENTIAL SITES EVALUATION}

NATURAL REGION

Site Name

Weighted Size Value ${ }^{1}$

Mixed Grassland

Alkali Creek

Bindloss Terraces (East)

Dinosaur Provincial Park

Duchess Springs

Dune Point

Empress Dunes

Lomond

Lost River

Milk River Canyon

Pinhorn

Sage Grouse-Pronghorn

Suffield (Middle Sand Hills)

Verdigris Coulee

Northern Fescue Grassland

Antelope Lake

Dowling Lake

Little Fish Lake

Middle Lake

Plover Lake

Foothills Grassland

Cypress Hills (SE corner)

Fort Macleod (east terrace)

Fort Macleod (west terrace)

Twin River

\section{Central Parkland}

Battle River

Dilberry Lake Provincial Park

Gough Lake

\section{8}

7.8

11.2

4

13.2

4.2

8

12

26.2

8

8

28

0

8

0

18.4

1

8

11.2

0

0

0

0

5.2

0
Lac Tremble

0

Lousana

Miquelon Lake Provincial Park

6.4

Neutral Hills

3.6

Oxville

Paintearth Coulee

Rumsey

Torlea

Vermilion Lakes

Wainwright (David Lake)

Wood Lake

Foothills Parkland

Paine-Beaverdam (Sec. 1) 8

Paine-Beaverdam (Sec. 29) 8

Sheppard Creek

8

Peace River Parkland

Fairview-Erinlodge $\quad 0.4$

Highland Park $\quad 0.6$

Kleskun Hill 0

Peace-Smoky Island 0

Saskatoon Island Provincial Park 0

Silver Valley

Main Foothills

Brazeau (a)

Grave Flats

8.2

Maccabee Creek

Marshybank Lake

18.8

Muskiki Lake

North Ram-Nice Creek

13

Ole Buck Mountain 
Owl River

Pheonix

Sand Creek

Upper Brazeau

Northern Outlier Foothills

Goose Mountain

Otauwau Lake

Timeu

Subarctic Boreal Forest

Horseshoe Lake

Hay River Boreal Forest

Bassett Lake

Swan Lake

Peace River Lowlands Boreal Forest

Pelican Portage

Mixed Wood Boreal Forest

Bear Lake

Bellis

Crow Lake

La Crete

Lloyd Creek

McLelland Lake-Fort Hills

Notlkewin-Peace

Owl River

Pine Creek/Athabasca

Primula

Wolf Lake
18.4

3.2

28

16

0

27.6

\section{2}

12

8

16

8

9.6

28

8

\section{Rocky Mountain Montane}

Canmore \#1

4

Cypress Hills Provincial Park

11.2

Kootenay Plains

14

Pigeon Mountain

8

Porcupine Hills Summit

10.6

Upper Bob's Creek

12.8

Rocky Mountain Sub-Alpine

Beehive (Sub-Alpine)

20.4

Elbow-Sheep Divide

Grizzly Creek

14.4

Kananaskis Provincial Park (NW) 16.6

Mt. Livingstone

8

Plateau (Sub-Alpine)

16.2

Rocky Mountain Alpine

Beehive (Alpine)

10.2

Cardinal Divide (Alpine)

16

Kananaskis Provincial Park (NW)

21

Plateau (Alpine)

Upper Evans-Thomas (Alpine)

12.2

Kazan Upland Canadian Shield

Wylie Lake

Athabasca Plain Canadian Shield

Athabasca Dunes

26.6

Source: Cottonwood Consultants 1983: 186-189. 


\section{REFERENCES}

Abel, N. and P. Blaikie. 1986. "Elephants, People, Parks and Development: the Case of the Luangwa Valley, Zambia." Environmental Management 10(6):735751.

Adamus, P.R. and G.C. Clough. 1978. "Evaluating Species for Protection in Natural Areas." Btological Conservation 13(3): 165-178.

Alberta Recreation and Parks. 1986. Policy Statement for the Ministry of Recreation and Parks. Revised Draft. Alberta Department of Recreation and Parks, Edmonton. 137 pages plus appendices.

Arnold, R.A. 1983. Ecological Studies of Six Endangered Butterflies (Lepidoptera, Lycaenidae): Island Biogeography, Patch Dynamics, and the Design of Habitat Preserves. Entomology Vol. 99. Berkeley: University of California Press.

Batisse, M. 1986. "Developing and Focusing the Biosphere Reserve Concept." Nature and Resources 22(3):2-11

Beebee, T.J.C. 1979. "Habitats of the British Amphibians (2):Surburban Parks and Gardens." Biological Conservation 15(4):241-257.

Bennett, D.H. 1986. "Triage as a Species Preservation Strategy." Environmental Ethics 8(1):47-58.

Blake, D.K. and J.P. Loveridge. 1975. "The Role of Commercial Crocodile Farming in Crocodile Conservation." Biological Conservation 8(4):261-272.

Boecklen, W.J. 1986. "Optimal Design of Nature Reserves: Consequences of Genetic Drift." Biological Conservation 38(4):323-338.

Boecklen, W.J. and N.J. Gotelll. 1984. "Island Blogeographic Theory and Conservation Practice: Species-Area or Specious-AreaRelationships?" Biological Conservation 29(1):63-80.

Bonnicksen, T.M. and E.C. Stone. 1985. "Restoring Naturalness to Natural Parks." Environmental Management 9(6):479-486.

Bossel, H. 1987. "Viability and Sustainability." Futures 19(2):114-128.

Buchanan, A. 1985. "Costa Rica's Wild West." Sierra 70(4):32-35.

Canadian Wildlife Service and U.S. Fish and Wildlife Service. 1986. North American Waterfowl Management
Plan. Catalogue No. CW 66-80/1986E, Minister of Supply and Services Canada, Ottawa. 19 pages.

Case, T.J. and M.L. Cody. 1987. "Testing Theories of Island Biogeography." American Scientist 75(4):401411.

Catton Jr., W.R. 1987. "The World's Most Polymorphic Species." Blascience 37(6):413-419.

Chase, A. 1983. "The Last Bears of Yellowstone." The Atlantic Monthly 251(2):63-73.

Clark, C.W. 1973. "The Economics of Overexploitation." In Managing the Commons, G. Hardin and J. Baden, eds., pages 82-95. San Francisco: W.H. Freeman and Company.

Cohn, J.P. 1986. "Surprising Cheetah Genetics." BioScience 36(6):358-362.

Conservation Foundation. 1987. "Conservationists Must Plan for Human Needs." Conservation Foundation Letter. January-February 1987. 8 pages.

Cottonwood Consultants Ltd. 1983. A Biophysical System Overview for Ecological Reserves Planning in Alberta. Alberta Department of Recreation and Parks, Edmonton. 271 pages.

Council on Environmental Quality and the Department of State. 1980. The Global 2000 Report to the Prestdent: Entering the Twenty-First Century. Vol. 2. Washington: Government Printing Office. 766 pages.

Crerar, A. 1986. "Anticipate and Prevent." Policy Options 7(9):3-7.

Cullen, R. 1985. "Rationing Recreation Use of Public Land." Journal of Environmental Management $21(3): 213-224$.

Davis, A.M. and T.F. Glick. 1978. "Urban Ecosystems and Island Biogeography." Environmental Conservation 5(4):299-304.

DeRoy, T. 1987. "When Aliens Take Over." International Wildlife 17(1):34-37.

Diamond, J.M. 1975. "The Island Dilemma: Lessons of Modern Blogeographic Studies for the Design of Natural Reserves." Biological Conservation 7(2): 129-146. 
...- 1976. "Island Biogeography and Conservation: Strategy and Limitations." Science 193(4257):1027-1029.

East, R. 1981. "Species-Area Curves and Populations of Large Mammals in African Savanna Reserves." Biological Conservation 21(2):111-126.

Eberhardt, L.L. 1977. "Optimal Policies for Conservation of Large Mammals, with Special Reference to Marine Ecosystems." Environmental Conservation $4(3): 205-212$.

Ehrlich, P.R. 1982. "Human Carrying Capacity, Extinctions, and Nature Reserves." Bioscience 32(5):331333.

Ehrlich, P.R. and H.A. Mooney. 1983. "Extinction, Substitution, and Ecosystem Services." Biascience 33(4):248-254.

Eidsvik, M.F. 1980. "National Parks and Other Protected Areas: Some Reflections on the Past and Prescriptlons for the Future." Environmental Conservation $7(3)$ : $185-190$.

Fife, D. 1971. "Killing the Goose." In Maraging the Commons, G. Hardin and J. Baden, eds., pages 76-81. San Francisco: W.H. Freeman and Company.

Fitzgerald, S.G. 1986. "World Bank Pledges to Protect Wildlands." Biascience 36(11):712-715.

Foose, T.J. 1986. "Riders of the Last Ark: The Role of Captive Breeding in Conservation Strategles." In The Last Extinction, L. Kaufman and K. Mallory, eds., pages 141-165. Cambridge, Massachusetts: The MIT Press.

Forman, R.T.T. and J. Baudry. 1984. "Hedgerows and Hedgerow Networks in Landscape Ecology." Environmental Management 8(6):495-510.

Forman, R.T.T. and M. Godron. 1981. "Patches and Structural Components for a Landscape Ecology." Bioscience 31(10):733-740.

Game, M. 1980. "Best Shape for Nature Reserves." Nature 287(5783):630-631.

Geist, V. 1985. “Game Ranching: Threat to Wildlife Conservation in North America." Wildlife Society Bulletin 13(4):594-598.

Gilliland, M.W. 1984. "A Conceptual Framework for Environmental Protection." Environmental Management 8(6):463-472.

Gilpin, M.E. and J.M. Diamond. 1980. "Subdivision of Nature Reserves and the Maintenance of Species Diversity." Nature 285(5766):567-568.
Goeden, G.B. 1979. "Biogeographic Theory as a Management Tool." Environmental Conservation 6(1):2732.

Goodland, R.J.A. 1980. "Environmental Ranking of Amazonian Development Projects in Brazil." Environmental Conservation 7(1):9-26.

Hanson, J.A. 1977. Towards an Ecologically-Based Economic Philosophy." Envirormental Conservation 4(1):3-10.

Hardin, G. 1974. "Living on a Lifeboat." Biascience 24(10):561-568.

...- 1983. "Sentiment, Guilt, and Reason in the Management of Wild Herds." The CoEvolution Quarterly No. 40 Winter:22-28.

...- 1986. "Cultural Carrying Capacity: A Biological Approach to Human Problems." Blascience 36(9):599-606.

Harris, L.D. 1984. The Fragmented Forest. Chicago: The University of Chicago Press. 211 pages.

Helliwell, D.R. 1975. 'The Concept of 'Waste' and the Conservation of Nature." Environmental Conservation 2(4):271-273.

--.- 1976. The Extent and Location of Nature Conservation Areas." Environmental Conservation 3(4):255-258.

Higgs, A.J. and M.B. Usher. 1980. "Should Nature Reserves Be Large or Small?" Nature 285(5766):568-569.

Hudson, R.J. 1982. “A Stochastic Model of Survival of Remnant Black Rhino Populations in Kenya, Africa." Biological Extinction 1(2):33-37.

-.-- 1984. The Potential of Wild Ruminants." Agrologist 13(1):14-15.

-.-. 1986. The Conservation by Utilization Paradox." The Game Grower 2(2):17-21.

Jablonski, D. 1986. "Mass Extinctions: New Answers, New Questions." In The Last Extinction, L. Kaufman and K. Mallory, eds., pages 43-61. Cambridge, Massachusetts: The MIT Press.

Johnson, R.R. and S.W. Carothers. 1987. "External Threats: the Dilemma of Reserve Management on the Colorado River in Grand Canyon National Park, U.S.A." Environmental Management 11(1):99-107.

Kahn, J. 1986. "Restoring the Everglades." Slerra $71(5): 38-43$.

Kaufman, L. 1986. "Why the Ark is Sinking." In The Last Extinction, L. Kaufman and K. Mallory, eds., pages 1-41. Cambridge, Massachusetts: The MIT Press. 
Kelcey, J.G. 1975. "Opportunities for Wildlife Habitats on Road Verges in a New City." Urban Ecology 1(2,3):27 1-284.

...- 1978. "The Green Environment of Inner Urban Areas." Environmental Conservation 5(3):197-203.

Kitchener, D.J., J. Dell, B.G. Muir, and M. Palmer. 1982. "Birds in Western Australia Wheatbelt Reserves Implications for Conservation." Biological Conservation 22(2): 127-163.

Kushlan, J.A. 1979. "Design and Management of Continental Wildlife Reserves: Lessons From the Everglades." Biological Conservation 15(4):281290.

----- 1987. "External Threats and Internal Management: the Hydrologic Regulation of the Everglades, Florida, U.S.A." Envtronmental Management 11(1):109-119.

Kuss, F.R. and J.M. Morgan III. 1986. “A First Alternative for Estimating the Physical Carrying Capacity of Natural Areas for Recreation." Environmental Management 10(2):255-262.

Larson, E.D., M.H. Ross, and R.H. Williams. 1986. "Beyond the Era of Materials." Scientific American 254(6):34-41.

Lennartz, M.R. 1979. "Multiple-Use Management for Some, A Promise Unfulfilled." In Multiple-Use Management of Forest Resources. Proceedings of a symposium held at Clemson University, Clemson, South Carolina, September 1979.

Lewin, R. 1986. "In Ecology, Change Brings Stability." Science 234(4780): 1071-1073.

Lusigi, W.J. 1982. "New Approaches to Wildlife Conservation in Kenya." The Ecologist 12(3): 101-106.

MacArthur, R.H. 1972. Geographical Ecology: Patterns in the Distribution of Specles. New York: Harper and Row. 320 pages.

MacArthur, R.H. and E.O. Wilson. 1967. The Theory of Island Biogeography. Princeton: Princeton University Press. 203 pages.

Mader, H.J. 1984. “Animal Habitat Isolation by Roads and Agricultural Flelds." Biological Conservation 29(1):81-96.

Maguire, L.A. 1986. "Using Decision Analysis to Manage Endangered Species Populations." Journal of Environmental Management 22(4):345-360.

Margules, C. and M.B. Usher. 1981. "Criteria Used in Assessing Wildlife Conservation Potential: A Review." Biological Conservation 21(2):79-109.

May, R.M. and A.M. Lyles. 1987. "Living Latin
Binomials." Nature 326(6114):642-643.

McClanahan, T.R. 1986. "Pollen Dispersal and Intensity as Criteria for the Minimum Viable Population and Species Reserves." Environmental Management $10(3): 381-383$.

McCoy, E.D. 1982. "The Application of IslandBiogeographic Theory to Forest Tracts: Problems in the Determination of Turnover Rates." Biological Conservation 22(3):217-227.

---- 1983. "The Application of Island-Biogeographic Theory to Patches of Habitat: How Much Land is Enough?" Biological Conservation 25(1):53-61.

Medwecka-Kornas, A. 1977. "Ecological Problems in the Conservation of Plant Communitles, with Special Reference to Central Europe." Environmental Conservation 4(1):27-33.

Moore, N.W. and M.D. Hooper. 1975. "On The Number of Bird Species in British Woods." Biological Conservation 8(4):239-250.

Moore, S.E., G.L. Lawson, and B. Ridley. 1986. "Population Control of Exotic Rainbow Trout in Streams of a Natural Area Park." Environmental Management 10(2):215-219.

Myers, J.P., R.I.G. Morrison, P.Z. Antas, B.A. Harrington, T.E. Lovejoy, M. Sallaberry, S.E. Senner, and A. Tarak. 1987. "Conservation Strategy for Migratory Species." American Scientist 75(1): 18-26.

Myers, N. 1986. "Faith in the Power of Seed." International Wildife 16(5):18-19.

Nagano, C. and C. Freese. 1987. "A World Safe for Monarchs." New Scientist April 2, 1987:43-47.

Newmark, W.D. 1987. “A Land-Bridge Island Perspective on Mammalian Extinctions in Western North American Parks." Nature 325(6103):430-432.

Norse, E.A, K.L. Rosenbaum, D.S. Wilcove, B.A. Wilcox, W.H. Romme, D.W. Johnston, and M.L. Stout. 1986. Conserving Biological Diversity in our National Forests. The Wilderness Society, Washington, D.C. 116 pages.

Noss, R.F. 1983. “A Regional Landscape Approach to Maintain Diversity." Biascience 33(11):700-706.

Noss, R.F. and L.D. Harris. 1986. "Nodes, Networks, and MUMs: Preserving Diversity at all Scales." Environmental Management 10(3):299-309.

O'Brien, S.J., D.E. Wildt, and M. Bush. 1986. "The Cheetah in Genetic Peril." Scientific American 254(5):84-92. 
Odum, W.E. 1982. "Environmental Degradation and the Tyranny of Small Decisions." Biascience 32(9):728729.

Office of Technology Assessment, U.S. Congress (OTA). 1986. Grassroots Conservation of Blological Diversity in the United States - Background Paper \#1. OTA-BP-F-38. Washington, D.C.: U.S. Government Printing Office.

Ola, P. and E. d'Aulaire. 1986. "Lessons From a Ravaged Jungle." International Wildlife 16(5):34-41.

Oldfield, M.I. 1984. The Value of Conserving Genetic Resources. U.S. Department of the Interior National Park Service, Washington, D.C. 360 pages.

Owen, D.F. 1976. "Conservation of Butterflies in Garden Habitats." Environmental Conservation 3(4):285290.

Oxley, D.J., M.B. Fenton, and G.R. Carmody. 1974. "The Effects of Roads on Populations of Small Mammals." Joumal of Applied Ecology 11:51-59.

Peters, R.L. and J.D.S. Darling. 1985. The Greenhouse Effect and Nature Reserves." Blascience 35(11):707-717.

Pickett, S.T.A. and J.N. Thompson. 1978. "Patch Dynamics and the Design of Nature Reserves." Biological Conservation 13(1):27-37.

Picton, H.D. 1979. "The Application of Insular Biogeographic Theory to the Conservation of Large Mammals in the Northern Rocky Mountains." Biological Conservation 15(1):73-79.

Pimentel, D., E. Garnick, A. Berkowitz, S. Jacobson, S. Napolitano, P. Black, S. Valdes-Cogliano, B. Vinzant, E. Hudes, and S. Littman. 1980. "Environmental Quality and Natural Biota." Bloscience 30(11):750-755.

Pinder, N.J., and J.P. Barkham. 1978. “An Assessment of the Contribution of Captive Breeding to the Conservation of Rare Mammals." Biological Conservation 13(3): 187-245.

Polunin, N. and H.K. Eidsvik. 1979. "Ecological Principles for the Establishment and Management of National Parks and Equivalent Reserves." Environmental Conservation 6(1):21-26.

Prescott-Allen, R. 1986. National Conservation Strategies and Biological Dwersity. IUCN Contract No. $\mathrm{CDC} / \mathrm{C} 80 / \mathrm{RPA}$, International Union for Conservation of Nature and Natural Resources, Conservation for Development Centre. 67 pages plus appendices.

Public Advisory Committees (PAC). 1986. Prospectus for an Alberta Conservation Strategy. ECA 86-PA/CS.
Public Advisory Committees to the Environment Council of Alberta, Edmonton. 78 pages.

Pyle, R., M. Bentzien, and P. Opler. 1981. "Insect Conservation." Annual Review of Entomology 26:233258.

Race, M.S. 1985. "Critique of Present Wetlands Mitigation Policies in the United States Based on an Analysis of Past Restoration Projects in San Francisco Bay." Environmental Management 9(1):7182.

Rapoport, E.H., G. Borioli, J.A. Monjeau, J.E. Puntler, and R.D. Oviedo. 1986. "The Design of Nature Reserves: A Simulation Trial for Assessing Specific Conservation Value." Biological Conservation 37(3): 269-290.

Reed, T.M. 1983. "The Role of Species-Area Relationships in Reserve Choice: A British Example." Biological Conservation 25(3): 263-271.

Renecker, L.A., and H.M. Kozak. 1986. "An Understanding of Game Ranching and Farming in Western Canada." The Game Grower 2(2):9-16.

Robinson, R. 1986. "Rings of Flowers." BlaSclence 36(6):363-365.

Rolston III, H. 1985. "Duties to Endangered Species." BiaSclence 35(11):718-726.

Romme, W.H. and D.H. Knight. 1982. "Landscape Diversity: The Concept Applied to Yellowstone Park." Blasclence 32(8):664-670.

Sagoff, M. 1986. "Process or Product? Ethical Priorities in Environmental Management." Environmental Ethics 8(2): 121-138.

Schonewald-Cox, C.M., and J.W. Bayless. 1986. "The Boundary Model: A Geographical Analysis of Design and Conservation of Nature Reserves." Btological Conservation 38(4):305-322.

Shaffer, M.L. 1981. "Minimum Population Sizes for Species Conservation." Biascience 31(2): 131-134.

Simberloff, D. and L.G. Abele. 1976. "Island Biogeography Theory and Conservation Practice." Science 191(4224):285-286.

Simberloff, D. and N. Gotelli. 1984. "Effects of Insularization on Plant Species Richness in the Prairle-Forest Ecotone." Blological Conservation 29(1):27-46.

Smith, P.G.R. and J.B. Theberge. 1986. "A Review of Criteria for Evaluating Natural Areas." Environmental Management 10(6):715-734.

Soule, M.E. 1985. "What is Conservation Biology?" BioSclence 35(11):727-734. 
Soule, M.E. and D. Simberloff. 1986. "What Do Genetics and Ecology Tell Us About the Design of Nature Reserves?" Biological Conservation 35(1):19-40.

Soule, M.E., B.A. Wilcox, and C. Holtby. 1979. "Benign Neglect: A Model of Faunal Collapse in the Game Reserves of East Africa." Biological Conservation 15(4):259-272.

Stottlemyer, R. 1987. "Evaluation of Anthropogenic Atmospheric Inputs on U.S. National Park Ecosystems." Environmental Management 11(1):91-97.

Strassman, B.I. 1987. "Effects of Cattle Grazing and Haying on Wildlife Conservation at National Wildlife Refuges in the United States." Environmental Management 11(1):35-44.

Struzik, E. 1986. "Sacred Trusts." Nature Canada 15(4):24-30.

Swinnerton, G.S. 1984. Conservation in Practice in Alberta: An Examination of the Role of Alberta Recreation and Parks. Department of Recreation and Leisure Studies, The University of Alberta, Edmonton. 447 pages.

Tangley, L. 1986. "Costa Rica - Test Case for the Neotropics." Bioscience 36(5):296-300.

Terborgh, J. 1974. "Preservation of Natural Diversity: The Problem of Extinction Prone Species." BloScience 24(12):715-722.

-.-- 1976. "Island Biogeography and Conservation: Strategy and Limitations." Sclence 193(4257): 1029-1030.

Usher, M.B. 1985. "Implications of Species-Area Relationships for Wildlife Conservation." Journal of Environmental Management 21(2):181-191.

Vida, G. 1978. "Genetic Diversity and Environmental Future." Environmental Conservation 5(2):127-
132.

Vilkitis, J.R. 1978. "Wildlife Habitat as an Integral Component of a Planned Unit Development." Urban Ecology 3(2):171-187.

Vitousek, P.M., P.R. Ehrlich, A.H. Ehrlich, and P.A. Matson. 1986. "Human Appropriation of the Products of Photosynthesis." Bioscience 36(6):368-373.

Walther, P. 1986. "The Meaning of Zoning in the Management of Natural Resource Lands." Journal of Environmental Management 22(4):331-343.

Weisburd, S. 1986. "Artificial Reefs." Science News 130(4):59-61.

Westman, W.E. 1977. "How Much Are Nature's Services Worth?" Sclence 197(4307):960-964.

Whitcomb, R.F., J.F. Lynch, P.A. Opler, and C.S. Robbins. 1976. "Island Biogeography and Conservation: Strategy and Limitations." Science 193(4257):1030-1032.

Wilcox, B.A. 1986. "Extinction Models and Conservation." Trends in Ecology and Evolution 1(2): 46-48.

Williamson, R.D. and R.M. DeGraaf. 1981. "Habitat Associations of Ten Bird Species in Washington, D.C." Urban Ecology 5(2): 125-136.

Wilson, E.O. 1985. "The Biological Diversity Crisis." BioScience 35(11):700-706.

Wolf, E.C. 1987. On the Brink of Extinction: Conserving the Diversity of Life. Worldwatch Paper 78. Worldwatch Institute. Washington, D.C. 54 pages.

Yapp, G.A. and G.C. Barrow. 1979. "Zonation and Carrying Capacity Estimates in Canadian Park Planning." Biological Conservation 15(3): 191-206.

Younghusband, P. and N. Myers. 1986. "Playing God with Nature." International Wildlife 16(4):4-13. 



